\title{
Five Local Studies of Nordic Emigration and Migration
}

By

\author{
Andres A. Svalestuen \\ The National Archives, Oslo
}

\section{Introduction}

In the following pages, I shall attempt to present the local micro-studies made within the framework of the research project "Nordic Emigration", to compare some of the results, and briefly comment on a few special problems dealt with in these reports.

From Finland we have Population movements in Toholampi during the years 1870-1889, by Reino Kero, assisted by Auvo Kostiainen, Esa Vainio and Eero Kuparinen; from Sweden Alfla socken 1871-90. Presentation av undersökningsområdet samt av befolkningsrörlighetens bakgrundsvariabler med hjälp av bl.a. AID-analys (Alfta parish 1871-90. Presentation of the research area and of the background variables of population mobility by means of AID-analysis), and Alfta sockens befolkningsrörlighet 1846-50, 1866-90. Presentation av en mikroundersokning samt exempel på några preliminära resultat (Population mobility of Alfta parish 1846-50, 1866-90. Presentation of a micro-study and some preliminary results), both by Kjell Soderberg; from Norway Utvandringen fra Ullensaker 1867-99 (Emigration from Ullensaker 1867-99), by Elisabeth Koren; from Denmark Aspekter af Torslev sogns demografiske og migratoriske forhold ca. 1870-1901 (Aspects of demographic and migratory conditions in the parish of Torslev ca. 1870-1901), by Arne Vangdrup; and from Iceland Emigration from Vopnafjördur 1873-93, by Júníus Kristinsson. ${ }^{1}$ The latter work was not made in immediate contact with the research group.

A lot of time and energy was spent in order to find representative and comparable districts for local investigations into the flow and structure of migrational movements. The commune or parish in question should preferably have a population of 3-5000 inhabitants, and be characterized by a marked migration intensity in the second 
half of the 19th century, both as regards internal and external migration. It should be a society dominated by an agrarian economy. Geographically, the district ought not to be situated within an urban field of influence, that is, the distance to the nearest town had to be more than 30 kilometers. Furthermore, the suitability of the central source material had to be tested in advance. A final condition was that the studies should fall within the time limits 1865-1900.

The questions of the representativity and comparability of the areas chosen were discussed repeatedly among the participants in the project. It soon became clear that it would be impossible to attain a high degree of comparability. For instance, when speaking of the social-occupational structure of emigration, only crude and approximate categories could be compared, because the same terms denoting social class or occupation to some extent covered different socio-economic realities in the five countries.

More important perhaps is the disparity of historical sources when we attempt to analyse and compare various migratory movements in the Nordic countries. Thus, the excellent material contained in the parish registers of Sweden and Finland constitutes a very good basis for a thorough examination both of internal migration (even within the communes): and emigration. On the other hand, the Danish and Norwegian material allow only a partial description of internal migration. The church registers are very incomplete as regards the information on in- and out-migrants, and as a rule only the residual figures or the net results of internal population movements can be estimated by comparing the excess of births of a given area with the census returns and the volume of emigration. However, information on the birth-places in the census material can give a rough indication of the volume and direction of internal migration, but the task of collecting this information from primary sources is time-absorbing. Strictly speaking, only miqration overseas can be compared accurately in the Nordic countries, but we may, of course, compare internal migration in Sweden and Finland. The Danish and Norwegian emigration statistics are chiefly based on registers (emigrant protocols) kept by the police authorities at the ports of embarkation, whereas the Swedish and Finnish ones rely on the parish registers, supplemented by passport journals and passenger lists.

There are, of course, other difficulties inherent in the organization of such a research project. As it is we must admit that the compara- 
tive micro-studies lack some of that homogeneity of structure which would have made them more comparable. Nevertheless, these studies make possible the comparison of several central aspects pertaining to emigration and migration, and focus attention on some problems of interest to migration history generally.

\section{Toholamgi, Alfta, Ullensaker, Torslev, and Vopnafjordur : a brief description}

Toholampi commune is situated in Vaasa province in Ostrobothnia, Finland. The distance to the nearest town - Kokkola - is about 60 kilometers. Toholampi had a population of 2569 inhabitants in 1865 and 2763 in 1891 . It was almost exclusively an agrarian district in the 19th century. The proportion of the independent farmer class fluctuated between $54 \%$ and $58 \%$ of the total population during the period 1870-90. The landless labourers (hired help) were the second largest group, 20-25\%. The tenant farmer class and the cottager class each represented less than $10 \%$ of the population. About $10 \%$ of the farms were tenant farms in 1881. The corresponding share in Vaasa province was $60.1 \%$. Toholampi then had an exceptionally high percentage of freeholders among the farmers. Most farm units were rather small, and the crop yields were relatively modest. The proportion of poor people (those who received public assistance) was $9.7 \%$ in 1865 , $4.1 \%$ in 1881 . In addition to agriculture, tar distilling was important to the economy, but this industry was in a decline from the 1870's.

The Toholampi study is a thorough statistical examination of migration within the parish, population movements to and from five neighbouring communes (short-distance migration), to and from other parts of Finland (long-distance migration), and more especially the emigration to America, 1870-89. The most important sources are the parish registration books, (general parish register, register of migrants). Information about the emigrants has also been drawn from the passport list - and the passenger lists of Gothenburg - since the majority of emigrants left by this port in the 1880 's. In this decade Toholampi had the strongest emigration ot all Ostrobothnian communes.

Alfta is a parish in the southwestern part of Walsingland province in Gavleborgs lan (county),Sweden. The central parts of the district belong to the Woxna valley, which opens into the coastal zone of 
Norrland; the rest is largely a rolling wooded landscape. In 1900 the majority of Alfta's population (4 280 in 1850) were still engaged in agriculture and forestry. The redistribution of farmer holdings (laga skifte) came into force from 1873, and this in turn stimulated improvements and rationalization within the agricultural sector. The farming productivity was relatively good. In Gavleborgs län the average farm unit in 1900 had 8 hectares of arable land, and $10 \%$ of the farmers were tenants (arrendatorer).

The rapid expansion of the saw mill and pulp industries in Norrland in the second half of the last century raised the value of the forests and improved the incomes of the peasant population. A large part of the peripheral forest areas in Alfta were sold to industrial share-holding companies. In other cases, rights of exploiting the timber resources were sold by the farmers. This industrial development also affected the economy of Alfta, although industrial installations in this parish were few before 1900 . The only industry of any, importance was Svabenverks Iron Works, which ceased production in 1876 . However, the wood processing industry and the railway-building resulted in higher wages and increased competition on the labour market. This in turn made labour scarce within the agricultural sector. According to a statement from the pastor of Alfta, cited in Emigrationsutredningen (the report of the Emigration Commission), young people fled away from traditional farm work, became accustomed to a higher wage level, and this made them more receptive to the "America fever".

Kjell Soderberg has analysed migration within the parish, the internal out-migration and emigration from Alfta $1871-90$ by means of AID-technique (Automatic Interaction Detector analysis). In addition, he has made a special study of the selection of migrants in comparison with the stationary population, concerning reading proficiency as it is recorded in the catechetical examination lists (husförhörslängder) by the local clergyman. A similar study of this qualitative aspect of the migrant mass was planned for Toholampi, but here the source material proved inadequate. Soderberg has based his work primarily on the parish registers. Alfta was one of the districts of Halsingland that had the highest frequency of emigration both during 1846-50, 1866-70, and in the 1880's.

Ullensaker parish and commune is situated in Øvre Romerike (formerly a bailiwick orfogderi) in Akershus county in Southeastern Norway. The distance to the capital city Oslo (Christiania) is about 40 kilometers from Jessheim, center of the parish. During the period 
in question Ullensaker was economically dominated by agriculture, typical of the grain-producing districts in this region of Norway, The parish occupies the central part of the Romerike plain.

The population of Ullensaker fluctuated violently during the second half of the 19th century, from a maximum of 7373 inhabitants in 1865 to a minimum of 5400 in 1891. Extensive emigration and internal migration, especially to Christiania, caused this reduction. The district had good connections with the capital city, both by road and railway (from 1854).

In 1865 the parish had 530 independent farmers, 20 tenant farmers, 348 cottagers, 746 servants, and 347 workers by the day. The number of tenants was reduced to only 2 in 1875 and the number of cottagers to 97 in 1891, while the number of freeholders was 476 in 1900 . Only 259 servants and 129 workers belonged to the agricultural sector in 1900. Generally, agriculture became integrated in the market economy and more capital intensive, and there was a shift from rather one-sided grain production to animal production. The introduction of more advanced technology further reduced the need for a numerous class of cottagers, servants and labourers.

The economy had become somewhat more diversified by the turn of the century. Thus, in 1900 there were 462 people over 15 years of age attached to various industrial activities, including handicrafts. 128 were independent craftsmen. The industrial enterprises were small, the most important being some flour mills, saw mills, brickworks, and textile firms, each employing only a very limited number of workers.

Elisabeth Koren concentrates her investigation on emigration from Ullensaker 1867-99. The main sources are the emigrant protocols, the census returns of 1865 and 1875, and the parish registers. Sivert Langholm has written an article on internal migration in Ullensaker, based on the census of 1865, Short-distance Migration, Circles and Flows: Movements to andfrom Ullensaker according to the Population Lists $₫ 1865 .^{2}$

Torslev is the Danish area chosen for this study. It is a parish in Dronninglund hundred (herred), Hjørring county, in northeastern Jutland. It was essentially a farming community with an average population somewhat exceeding 2000 persons in the period 18701901. Torslev is situated 11 kilometers west of the town Sæby and 40 kilometers to the northeast of Aalborg, the fourth biggest town of Denmark. Arne Vangdrup has made a micro-study of emigration 
overseas, and of migration to the neighbouring parish of Skæve and seven towns receiving people from Torslev. He utilized the same kind of source material as Elisabeth Koren and others in the case of Ullensaker. Torslev was an area of high emigration frequency, especially in a Danish context.

Júníus Kristinsson is the author of Emigration from Vopnafjördur 1873-93. Vopnafjordur is a parish in the northeastern part of Iceland, with a population amounting to about 1000 people in 1860 . In this locality agriculture was also the mainstay of the economy, especially sheep breeding. Fishing was of subsidiary importance for some farmers on the coast-line. It was only after 1880 that the fisheries became more exploited. From then on there was a concentration of people around the market place in the local village.

\section{Population Development and Geographical Mobility.}

\section{A Survey}

\section{Toholampi}

During the period $1805-80$ the population increased by $123.4 \%$ in Finland and by $140.8 \%$ in Vaasa province. For Toholampi commune figures are available from 1840 (Table 1).

Toholampi experienced a rapid population growth in the 1840 's and 1870's. Growth was slow in the $1850^{\prime}$ s, and in the second half of the 1860 's the population declined by 227 persons, being a result of crop failures and the famine that ravaged the Finnish countryside during these years. In 1868 there were only 51 births in Toholampi, whereas 252 died. In spite of a greater birth surplus in the 1880's compared to the 1870 's, the population in the former decade was almost stagnant, which must be ascribed to the very heavy emigration from the district during 1880-90. The annual average birth

Table 1. Population in Toholampi 1840-91.

\begin{tabular}{lllll} 
Year & Population & & Year & Population \\
\cline { 1 - 2 } 1840 & 1958 & & 1870 & $2342-8,8 \%$ \\
1850 & $2440+24,6 \%$ & & 1880 & $2765+18,0 \%$ \\
1860 & $2525+3,5 \%$ & & 1891 & 2763 \\
1865 & 2569 & &
\end{tabular}

Source: Reino Ke1o, Population movements in Toholampi during the years 1870-1889, Turku 1976, p. 11. 
rate was $42.5 \%$ for $1870-80$ and $45.6 \% 1880-90$. Of the total number of deaths about $30 \%$ were children younger than five years old and about $35 \%$ children younger than ten years old.

1529 persons were registered as out-migrants and 1079 as inmigrants in the two decades from 1870 to 1889 (Table 2). Population exchange with neighbouring communes brought about a net loss of 50 peoplè, and migration to and from other parts of Finland resulted in a small net gain of 17 persons. During the same period 1896 persons migrated within the commune. However, this material also indicates that internal migrations, especially the short-distance movements, tended to outweigh each other. In Toholampi the emigration to America was largely responsible for the markedly negative migration balance during the $1870-89$ period. We should also note that very considerable in- and out-migration across the borders of a given area may occur, without' this being reflected in the net migration figures. These are then a most unreliable measure of migration intensity. Even before emigration started in the 1870 's, Toholampi was a district of negative migration balance. In the period 1845-69 only the years $1845-49$ had a greater number of in-migrants than out-migrants.

Population mobility was relatively low in the 1860's (famine years), but increased in the following decade and became very high during 1880-89 (Table 3 ). From the second half of the 1860's longdistance movements became more frequent than short-distance movements, i.e. to the five neighbouring communes. At the same time migration to urban areas started to increase. Town migrants represented $19 \%$ of all migrants from and to Toholampi during 1870-74, and later on this declined to 10-12\%. Kokkola (Gamlakarleby) was the main destination of those leaving for a town. In the 1880's Viipuri was most important. Migration to Viipuri was

Table 2. Migrations from and to Toholampi 1870-89.

\begin{tabular}{lccc}
\hline \multicolumn{1}{c}{$\begin{array}{c}\text { Areas of destination and } \\
\text { departure }\end{array}$} & $\begin{array}{c}\text { Out-migrants } \\
\text { to }\end{array}$ & $\begin{array}{c}\text { In-migrants } \\
\text { from }\end{array}$ & $\begin{array}{c}\text { Net- } \\
\text { migration }\end{array}$ \\
\hline Neighbouring communes (5) & 462 & 412 & -50 \\
Other parts of Finland & 554 & 571 & +17 \\
America & 513 & 96 & 417 \\
\hline Total & 1529 & 1079 & -450 \\
\hline
\end{tabular}

Source: Kero, pp. 72-77. 
Table 3. Population movements in Toholampi 1870-89.

\begin{tabular}{|c|c|c|c|c|c|c|c|c|}
\hline & \multicolumn{2}{|c|}{$1870-74$} & \multicolumn{2}{|c|}{$1875-79^{\prime}$} & \multicolumn{2}{|c|}{$1880-84$} & \multicolumn{2}{|c|}{$1885-89$} \\
\hline & $\mathrm{N}$ & $\%$ & $\mathrm{~N}$. & $\%$ & $N$ & $\%$ & $\mathrm{~N}$ & $\%$ \\
\hline To America & 32 & 4,4 & 15 & 1,8 & 147 & 11,2 & 319 & 19,4 \\
\hline \multicolumn{9}{|l|}{ To other parts of } \\
\hline Finland & 111 & 15,4 & 154 & 18,7 & 115 & 8,8 & 169 & 10,3 A \\
\hline \multicolumn{9}{|l|}{ To neighbouring } \\
\hline communes & 107 & 14,9 & 114 & 13,8 & 170 & 13,0 & 76 & 4,6 \\
\hline Internal movements & 254 & 35,3 & 306 & 37,1 & 612 & 46,7 & 724 & 43,9 \\
\hline From America & 一 & - & 11 & 1,3 & 16 & $1 ; 2$ & 69 & 4,2 \\
\hline \multirow{2}{*}{$\begin{array}{l}\text { From other parts of } \\
\text { Finland } \\
\text { From neighbouring } \\
\text { communes }\end{array}$} & 107 & 14,9 & 131 & 15,9 & 130 & 9,9 & 196 & 11,9 \\
\hline & 109 & 15,1 & 94 & 11,4 & 121 & 9,2 & 95 & 5,8 \\
\hline Total & \multicolumn{2}{|c|}{720100} & \multicolumn{2}{|c|}{825100} & \multicolumn{2}{|c|}{1311100} & \multicolumn{2}{|c|}{1648100} \\
\hline
\end{tabular}

Source: Kero, tab. 3, p. 18.

partly influenced by economic expansion in the St. Petersburg area. Short-distance movements were numerically greatest during 188084 , but were sharply reduced during 1885-89. Emigration overseas began in the 1870's, and increased to a mass movement in the 'eighties. In the Iast five-year period of the decade almost $20 \%$ of all registered migrants were emigrants, and emigration became the greatest out-migration stream from Toholampi. However, it is interesting to note that migration within the commune was constantly increasing during the period investigated - from about 35\% of total migration during the 'seventies to about $45 \%$ during the 'eighties. Two main categories of people moved within the commune: hired hands and servant maids who changed working place, and persons - especially women - who moved because of marriage. One-third of all the internal migrants in the 1870's moved because of marriage.

\section{Alfta}

The population of Alfta more than doubled between 1749 and 1850, from 1885 to 4280 inhabitants, with about 2900 in 1800 . At the end of the 1880's the population had increased to 5000 , in spite of heavy out-migration in the preceding decades. The mean population fluctuated between 4525 and 5066 in the period from 1871 to 1890 , but population growth continued until 1929 (Table4). 
Table 4. Average yearly population growth $1750-1930$, expressed in permille of mean population.

\begin{tabular}{ccc} 
& Alfta & Sweden \\
\hline $1750-1800$ & 7,72 & 5,52 \\
$1800-1850$ & 8,51 & 7,91 \\
$1851-1900$ & 6,27 & 7,76 \\
$1901-1930$ & 7,93 & 5,97 \\
\hline $1750-1930$ & 7,62 & 6,79
\end{tabular}

Source: Kjell Soderberg, Alfta socken 1871-90. Presentation av undersökningsområdet samt av befollmingsrorlighetens bakgrundsvariabler med hjälp av bl.a. AID-analys, Umeå 1974, tab. 1, p. 12.

Alfta parish is situated within the demographic area that Gustaf Sundbarg calls Eastern Sweden. Accordingly, we would expect it to be characterized by low fertility - in spite of high marriage rates and low marriage age - high mortality, small out-migration, and a moderate population increase.

Alfta, like Eastern Sweden, had low birth rates up to 1870 but from then on the birth rates were higher than those for Sweden as a whole, especially in the 1870's and 1880's. A relatively high birth level (about 30\%) continued right up to 1920.

Mortality in Alfta was below the national average until about 1875 and higher in the 1875-1900 period. Increased mortality thus coincided with increased nativity.

In this way the demographic development of Alfta differed from the pattern for Eastern Sweden established by Sundbarg, apart from the low nativity recorded before 1870 and a relatively high mortality during 1875-1900. In Sweden, mortality showed a constantly falling trend from about 1820, whereas natality was not substantially reduced until after 1870 . In Alfta, mortality rates fell below 20\% at the end of the 18th century, and fluctuated about 16-17\% between 1825 and 1850 (a level reached by the entire country around 1900). In the second half of the 19th century mortality rose and the birth rates remained on the traditional level until 1920. The process known as the demographic transition thus occurred at a later date in the parish of Alfta than in the kingdom of Sweden.

When we look at the migratory movements, Alfta also differed from Eastern Sweden, both internal migration and emigration being of great importance.

Unlike Toholampi, Alfta had a considerable surplus of in- 
Table 5. Alfta parish. Migrations 1871-90. Absolute figures.

\begin{tabular}{|c|c|c|c|c|c|}
\hline Years & $\begin{array}{l}\text { Out- } \\
\text { migration }\end{array}$ & $\begin{array}{c}\text { In- } \\
\text { migration }\end{array}$ & Emigration & Immigration & $\begin{array}{l}\text { Migration } \\
\text { within the } \\
\text { commune }\end{array}$ \\
\hline $1871-75$ & 224 & 203 & 41 & 15 & 619 \\
\hline $1876-80$ & 173 & 296 & 42 & 1 & 627 \\
\hline $1881-85$ & 226 & 330 & 326 & 22 & 894 \\
\hline $1886-90$ & 214 & 438 & 214 & 13 & 758 \\
\hline \multirow[t]{2}{*}{ Total } & $83 \%$ & 1267 & 623 & 51 & 2898 \\
\hline & \multicolumn{2}{|c|}{+430} & \multicolumn{2}{|c|}{-572} & \\
\hline
\end{tabular}

Source: Soderberg, appendix, tab. 2.

migrants (430) in the population exchange with the rest of the country (Table5). The total migration balance was positive between 1876 and $1880(+82)$ and between 1886 and $1890(\mathbf{\$ 2 3})$; it was negative between 1871 and 1875 ( -47$)$ and between 1881 and 1885 $(-190)$. Heavy emigration caused this marked net loss of people in the early 1880's, although Alfta only lost about 110 persons more than it received in the twenty years from 1871 to 1890 . Thus we can say that the migration pattern was more balanced in this parish than in the Finnish commune.

By the 1880's emigration had become a generation-old phenomenon in Alfta, and there was a kind of tradition in going to America. Early emigration from Alfta, especially in 1846, was almost exclusively made up of the so-called Erik Janssonists, members of a dissenting religious sect that had a strong following in Halsingland. These people came into bitter controversy with the established church of Sweden, and most of them emigrated to America, where they founded the well-known colony of Bishop Hill, led by the "prophet" Erik Jansson. Almost one-third of the 1500 Janssonists who emigrated between 1846 and 1854 came from Alfta. This was more than $10 \%$ of the total population of the parish at that time. Emigration from Alfta was also extensive during the depression years from 1866 to 1870 (221 persons). And, as we have seen, the third emigration wave came in the 1880's, especially 1881-85, when Alfta had the second highest emigration frequency in Gavleborgs lan.

It should be noted, however, that movements within the parish are by far the most common migratory phenomenon in Alfta, just as in Toholampi. In fact, migrants within the commune are more 


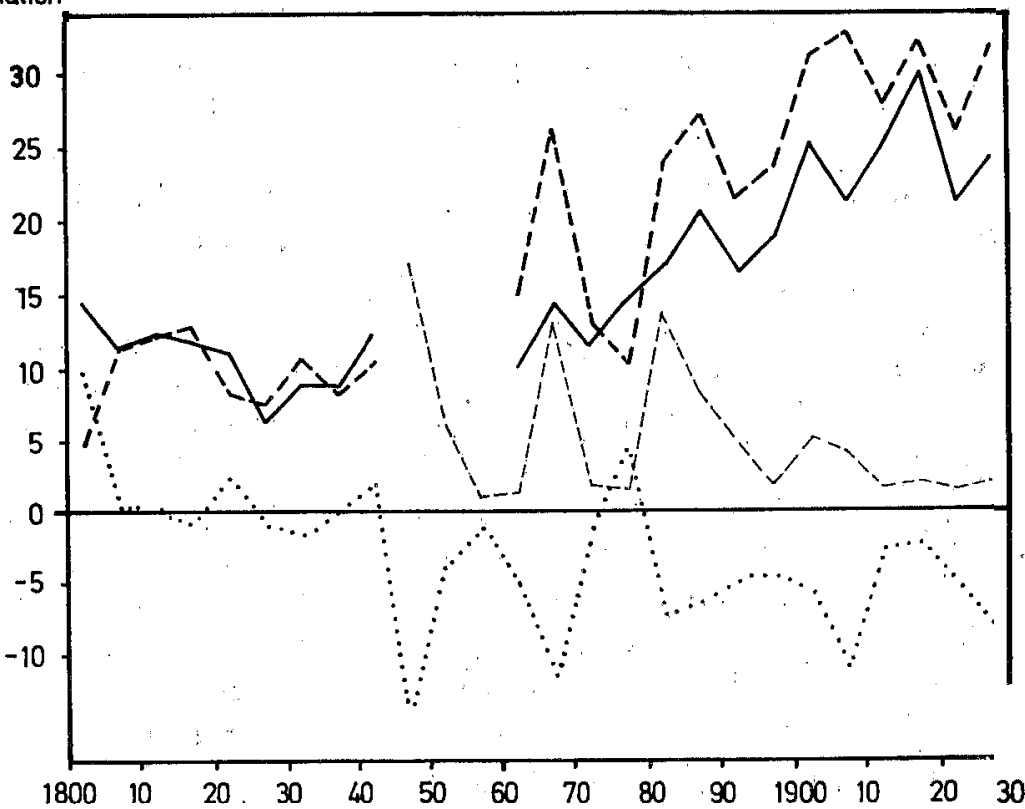

\section{In-migration \\ -... Out-migration \\ - - - Proportion of emigrants among out-migrants \\ ...... Net-migration}

Figure 1. In- and out-migration in Alfta 1801-1930, permille of mean population in five-year periods.

Source: Kjell Soderberg, Alfta sockens befolkningsrorlighet 1846-50, 1866-90. Presentation av en mikroundersokning spmt exempel $\mathrm{p} \mathrm{i}$ några preliminara resultat. Umeå 1976, diagram 4, p. 16.

numerous than all other migrants taken together in the 1870's. Increased mobility across the parish borders was caused chiefly by increased emigration and internal in-migration in the 1880's. Generally speaking, the net migratory balance was negative after 1850. After 1890 emigration to America was much less voluminous. Internal in- and out-migration continued, however, on an extensive scale (see Figure 1).

\section{Ullensaker}

During the wartime and famine years at the beginning of the 19th century, the population of Ullensaker was reduced by $15.7 \%$. In the period 1801-15 there was a death surplus of 220 and a net out- 
migration of 421 persons. From then on population increased by about $114 \%$ until 1865. During the next 25 years Ullensaker's population was again drastically reduced, by 2000 up to 1891 (about 27\%), beginning a period of slow growth in the decade before 1900 (Table 6).

It was above all the decades 1815-25, 1845-55, and 1855-65 that were characterized by rapid population increase, with annual average birth rates of $42.6,34.1$ and $34.9 \%$ respectively. The crude mortality rate sank definitely below $20 \%$ per year during the period 1846-55 and after 1865 both natality and mortality showed a tendency to decline, rising slightly towards the turn of the century (Table 7).

Apart from the penetrating study made by S. Langholm on the 1865 census material, there is not much to be said about migration from and to Ullensaker before 1865 . The only ten-year period in the 19th century with a marked surplus of in-migrants was 1816-25 (586). From 1826 to 1855 internal out- and in-migration were, generally speaking, of equal importance. Then, from 1856 to 1865 , net out-migration suddenly rose to 229 persons. In the period under investigation, 1865-1900, population development in Ullensaker

Table 6. Population in Ullensaker 1801-1900.

\begin{tabular}{cccccc}
\hline Year & Population & \% increase & Year & Population & \% increase \\
\hline 1801 & 4079 & & 1855 & 6493 & 17,0 \\
1815 & 3438 & $-15,7$ & 1865 & 7373 & 13,6 \\
1825 & 4708 & 36,9 & 1875 & 6031 & $1-8,2$ \\
1835 & 5271 & 12,0 & 1891 & 5400 & 40,5 \\
1845 & 5548 & 5,3 & 1900 & 5731 & 6,1 \\
\hline
\end{tabular}

Source: Elisabeth Koren, Utvandringen fra Ullensaker 1867-99, Oslo 1976, tab. 4a. Nos XII 108. Population census 1960, vol. 1, Oslo 1963, p. 188.

Table 7. Annual birth rates and death rates in Ullensaker 1865-1900, expressed in permille of mean population.

Birth rates Death rates

\begin{tabular}{lll}
\hline $1865-1875$ & 27,1 & 18,2 \\
$1875-1891$ & 26,1 & 17,3 \\
$1891-1900$ & 30,7 & 19,5 \\
\hline
\end{tabular}

Source: Koren, tab. 4c. 
Table 8. Population growth, emigration, and net migration from Ullensaker 1865-1900.

\begin{tabular}{|c|c|c|c|c|c|c|c|}
\hline Year & $\begin{array}{l}\text { Birth } \\
\text { surplus }\end{array}$ & $\begin{array}{l}\text { Ex- } \\
\text { pected } \\
\text { rate of } \\
\text { growth } \\
\% \\
\%\end{array}$ & $\begin{array}{c}\text { Emigra- } \\
\text { tion }\end{array}$ & $\begin{array}{c}\text { Emigra- } \\
\text { tion } \\
\%\end{array}$ & $\begin{array}{l}\text { Net out- } \\
\text { migra- } \\
\text { tion } \\
\text { (in- } \\
\text { ternal) }\end{array}$ & $\begin{array}{c}\text { Net out- } \\
\text { migra- } \\
\text { tion } \\
\%\end{array}$ & $\begin{array}{c}\text { Actual } \\
\text { growth } \\
\%\end{array}$ \\
\hline $1865-1875$ & 594 & 8.8 & 852 & 12.7 & 1084 & 16.2 & -20.0 \\
\hline $1875-1891$ & 755 & 8.8 & 725 & 8.5 & 661 & 7.7 & -7.4 \\
\hline $1891-1900$ & 570 & 11.3 & 213 & 4.2 & 26 & 0.5 & +3.1 \\
\hline 1865-1900 & 1919 & & 1790 & & 1771 & & \\
\hline
\end{tabular}

Source: Koren, tab. 4b.

may be illustrated by Table 8 (all rates in yearly $\%$ of mean population).

The migrational movements across the parish borders increased dramatically and reached a peak during 1865-75. Unfortunately, we usually only have the net figures of internal migrations, but these show that internal out-migration must have been very extensive from the second half of the 1860's, at the same time as emigration was at its highest. Both emigration and internal net out-migration decreased after 1875 , but particularly emigration overseas was still intensive at the beginning of the 1880's. Emigration and migration caused a very heavy population loss during 1875-91. This tendency was reversed later owing to reduced emigration, but, above all, it seems, due to an approximative balance in the internal population turnover 1891-1900.

Some preliminary results regarding the direction of internal outmigration from the parish indicate that the neighbouring communes and Christiania were the main destinations of this migratory movement. Thus the number of Ullensaker-born persons in Christiania rose from 411 to 921 in 1865-75. In 1865, 691 persons born in Ullensaker were living in five neighbouring parishes. The corresponding number of in-migrants from these districts was 794 .

\section{Torslev}

According to the census returns the number of inhabitants in Torslev parish doubled in the period 1801-60, and increased by one-third in the next forty years (Table 9).

Torslev parish had both the most rapid population increase and 
Table 9. Population in Torslev 1801-1901. Population growth 1850-1901 and emigration c:a 1870-1901 in Hjørring county, Dronninglund hundred and Torslev parish.

$\begin{array}{lrrrrrrr}\text { Population in Torslev } & & & & & & \\ 1801^{1 .} & 933 & 1850 & 1422 & 1870 & 1928 & 1890 & 2264 \\ 1840 & 1223 & 1860 & 1828 & 1880 & 2125 & 1901 & 2429\end{array}$

Population grawth amd emigration

Population growth
$1850-1901(\%)$

\begin{tabular}{lcc}
\hline Hjørring & 51 & 9,5 \\
Dronninglund & 55 & 12,0 \\
Torslev & 71 & 16,0 \\
\hline
\end{tabular}

Source: Arne Vangdrup, Aspekter af Torslev Sogns demografiske og migratoriske forhold 1870-1901, pp. 34 , and supplementary information.

Table 10. Population increase, birth surplus, net migration etc. in Torslev during 1860-1900. Absolute figures and \% yearly of mean population.

\begin{tabular}{lcccrrr}
\hline & $\begin{array}{c}\text { Popu- } \\
\text { lation } \\
\text { growth }\end{array}$ & $\begin{array}{c}\text { Birth } \\
\text { surplus }\end{array}$ & $\begin{array}{c}\text { Net out- } \\
\text { migra- } \\
\text { tion }\end{array}$ & $\begin{array}{c}\text { Net out- } \\
\text { migra- } \\
\text { tion } \\
\%\end{array}$ & $\begin{array}{c}\text { Expected } \\
\text { growth } \\
\%\end{array}$ & $\begin{array}{c}\text { Actual } \\
\text { growth } \\
\%\end{array}$ \\
\hline $1860-1869$ & 100 & 330 & 230 & 12.6 & 18.0 & 5.5 \\
$1870-1879$ & 197 & 358 & 161 & 8.4 & 18.6 & 10.2 \\
$1880-1889$ & 139 & 458 & 319 & 15.0 & 21.6 & 6.5 \\
$1890-1900$ & 165 & 572 & 407 & 18.0 & 25.3 & 7.3 \\
\hline $1860-1900$ & 601 & 1718 & 1117 & & & \\
\hline
\end{tabular}

Source: Vangdrup, tab 1, p. 4.

the most extensive emigration in Hjørring county in the period 1850-1901. It will be noted that population growth slackened considerably after 1860. But emigration and internal migration never brought about a stagnant population, as was the case in Toholampi, or a direct reduction as in Ullensaker. Hjørring county, and especially Torslev, had a considerably higher birth rate than the average birth rate of all rural districts in Denmark - in spite of the fact that the marriage rate was lower in these districts than in all of Denmark during 1860-1901. However, Torslev had relatively twice as many children born outside marriage as the Danish rural districts 


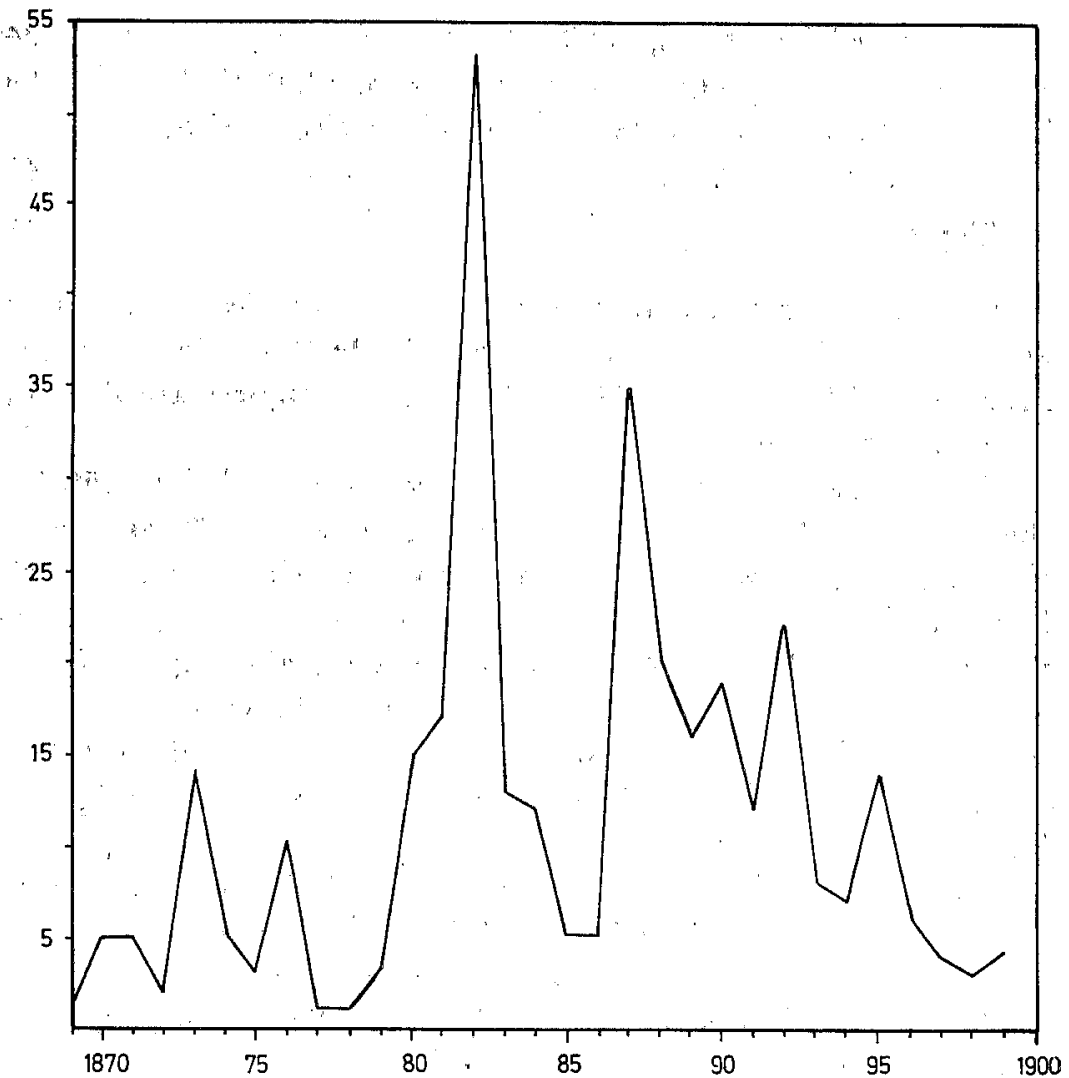

Figure 2. Annual emigration from Torslev.

Source: Arne Vangdrup, Aspekter af Torslev sogns demografiske og migratoriske forhold ca. 1870-1901. Copenhagen 1976, figure I.

(20.0\% and $9.7 \%$ of all born $1860-69$, respectively) and the Torslev women were, on an average, 2 years younger when they married.

Torslev was an area constantly losing more people than it received through migrations. The number of out-migrants was always greater than the number of in-migrants. In spite of this, population rose by about 600 persons from 1860 to 1900 . Net out-migration was relatively strong in the 1860's, with a marked levelling off in the following decade. The migration frequency then made a jump upwards in the 1880's, and continued to grow until the turn of the century. Thus the net migration rate rose from $8.4 \%$ annually in the decade $1870-79$ to $18.0 \%$ during 1890-1900 (Table 10).

The volume of the different migrational streams from Torslev can be illustrated by the following figures: 
1. Registered emigrants, 1868-99

2. Registered out-migrants to seven towns, 1870-1901

3. Short-distance migrants to the neighbouring parish, Skæve, 1870-1901

It should be stressed that internal out-migrants are registered according to information about the Torslev-born in the census material of 1870, 1880, 1890, and 1901. The figures are therefore only approximations.

The emigration volume from Torslev corresponded to $156 \%$ of the mean population during $1870-1900$, i.e. about $5 \%$ as a yearly average. But, as we see, migration to the neighbouring district Skæve and migration to towns were more voluminous than migration overseas. Vangdrup's study allows a certain degree of comparison as to these three migration streams. In what respect did town migrants differ from Skæve migrants and the emigrants?

As in all the other localities presented in this survey, emigration from Torslev fluctuated sharply from a minimum of $1.78 \%$ (yearly average of mean population) in the years 1875-79 to a maximum of $10.03 \%$ in $1880-84$. The diagram (Figure 2) illustrates the sudden variations of the emigration volume from year to year. In fact, $54 \%$ of the emigrants are registered in the 1880 's, and $16 \%$ in the single year of 1882 .

\section{Vopnafjördur}

The population of Iceland rose from about 48000 in 1820 to about 70000 in 1870, due, above all, to an increase in the birth rate, the mortality rate remaining practically unchanged. After 1870 both birth rate and mortality rate dropped markedly, but this resulted in about the same natural increase as before. However, the heavy emigration from Iceland prevented any significant population growth during the rest of the 19th century, at least until $1890 .^{3}$

In Vopnafjördur the number of inhabitants rose from approximately 400 in 1820 to 1000 in 1860 or by about $150 \%$, whereas population growth in Iceland as a whole was only $40 \%$. Thus the average annual population increase was $3.0 \%$ and $4.25 \%$ in Vopnafjordur in the decades 1830-40 and 1850-60, while the corresponding rates for Iceland were $0.71 \%$ and $1.10 \%$. From 1860 to 1900 the population figures fluctuated a great deal, with a general tendency to decline - to about 900 inhabitants at the end 
of the 1890 's. Iceland's total population increased at the same time by about $17 \%$.

Both birth rate and death rate were higher in Vopnafjordur than otherwise in Iceland, but the span between the birth curve and the death curve was greater in the local district, thus resulting in a greater birth surplus. However, over one-third of the population increase from 1820 to 1860 can be ascribed to a very marked inmigration to the area, especially in the periods 183140 and 185160 , characterized by an unprecedented population growth (Table $11)$.

The migration pattern completely changed about 1870 (Figure 3). Before that time Vopnafjordur may be characterized as an inmigration area; after 1870 and until 1900 the net loss through outmigration and emigration outnumbered the net gain by in-migration

Table 11. Birth and death rates in Iceland and Vopnafjordur 1821-1900. Average permillages of mean population.

\begin{tabular}{cccc}
\hline & & Iceland & Vopnafjordur \\
\hline \multirow{2}{*}{ Birth rate } & $1821-1870$ & 38.7 & 42.6 \\
& $1871-1900$ & 31.4 & 37.0 \\
Death rate & $1821-1870$ & 30.9 & 31.5 \\
& $1871-1900$ & 23.2 & 27.1 \\
\hline
\end{tabular}

Source: Júníus Kristinsson, Emigration from Vopnafjordur 1873-1893, Reykjavik 1973, tab. II-3, p. 6.

Table 12. Vopnafjordur. Net in- and out-migration 1821-1900. Migrations $1873-1893$.

\begin{tabular}{|c|c|c|c|c|c|}
\hline \multicolumn{6}{|l|}{ Net in-migration } \\
\hline $1821-30$ & $1831-40$ & $1841-50$ & $1851-60$ & $1861-70$ & Total \\
\hline $14 \cdot$ & 47 & 38 & 104 & 7 & 210 \\
\hline \multicolumn{6}{|l|}{ Net out-migration } \\
\hline $1871-80$ & $1881-90$ & $1891-1900$ & Total & & \\
\hline 164 & 38 & 45 & 247 & & \\
\hline \multicolumn{6}{|c|}{ Migrations to and from Vopnafjördur } \\
\hline $\begin{array}{c}\text { Internal } \\
\text { in-migrants }\end{array}$ & $\begin{array}{c}\text { Internal } \\
\text { out-migrants }\end{array}$ & $\begin{array}{l}\text { Net internal } \\
\text { gain }\end{array}$ & $\begin{array}{c}\text { Emigra- } \\
\text { tion }\end{array}$ & migr & $\begin{array}{l}\text { tal } \\
\text { on loss }\end{array}$ \\
\hline 1067 & 750 & 317 & 756 & & \\
\hline
\end{tabular}

Source: Kristinsson, p. 8, 12 and 31. 
1820-70. It is, however, interesting to note that Vopnafjordur, just like Alfta in Sweden, received a net gain from internal migration even after 1870. But from 1873 emigration to America began. 756 emigrants have been registered lor the years 1873-93, a number almost equal to that of internal out-migrants during the same period. Consequently, the total migration balance shows a loss of some 430 people for the two decades from 1873 to 1893 (Table 12).

Considering the size of population, the migration volume of Vopnafjordur was very great indeed, even more extensive than that of Toholampi. Emigration fluctuated very much from year to year, the peak years being 1876, 1878-79, 1887-89, and 1893.

Following a period of rapid population increase, the heightened geographical mobility manifested itself both in internal and external migrations. As far as we can judge from the present case-studies, migration within the home commune and other short-distance

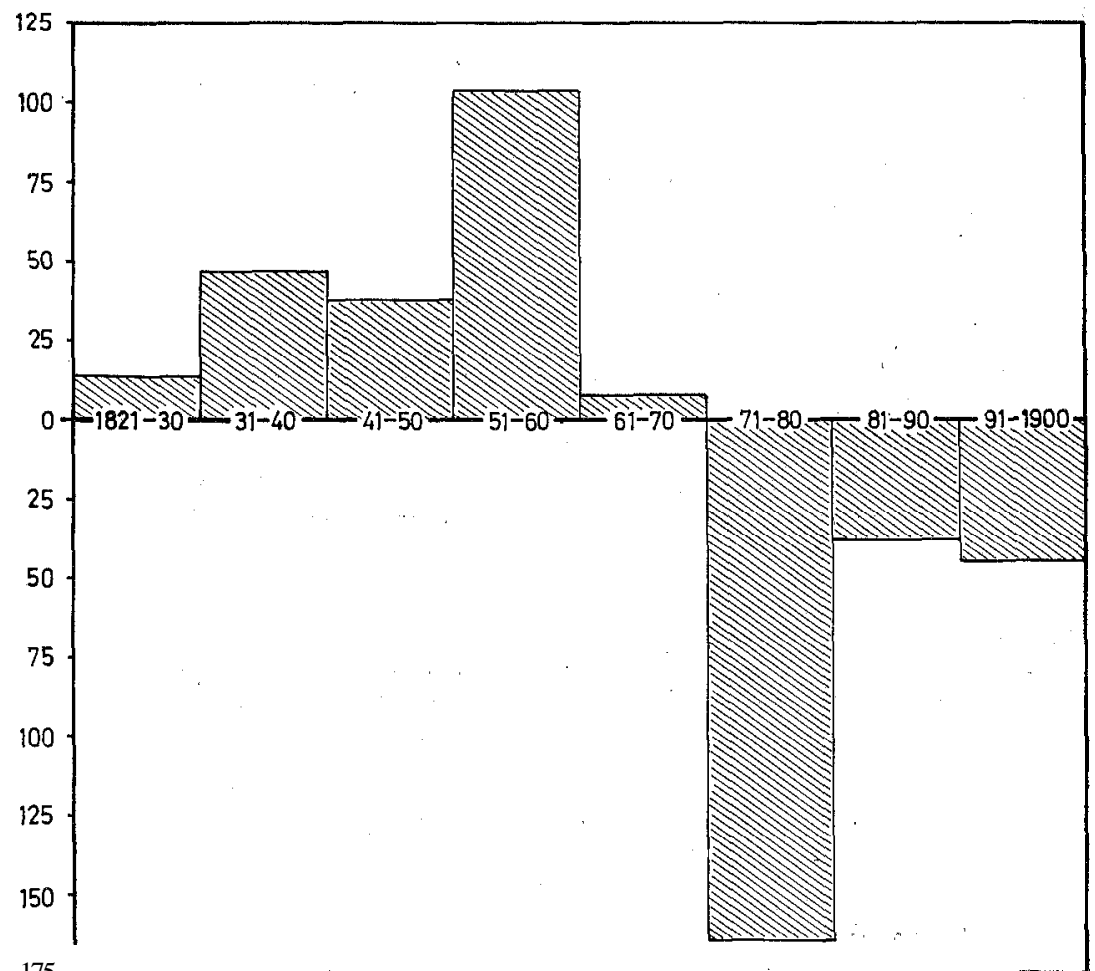

Figure 3. Net migration in Vopnafjordur 1821-1900.

Source: Júníus Kristinsson, Emigration from Vopnafjördur 1873-93. Reykjavik 1973, figure II-2, p. 8. 
migrations were the most numerous ones. Internal population exchange across the parish boundaries might largely be in balance (Toholampi), result in a surplus of in-migrants (Alfta, Vopnafjordur), or in a considerable net out-migration (Ullensaker, Torslev). Mass emigration to America and other long-distance migrations, especially to towns, were only followed by a small stream of people in the opposite direction. These were then, in a way, the most effective forms of migration. In Toholampi, Alita, and Vopnafjordur it was above all emigration that caused the negative migration balance in the period investigated. Ullensaker lost about the same number of persons through internal migration as through emigration, while Torslev was more heavily drained by internal migration losses.

\section{External and Internal Migrations. A Complex Pattern}

One of the aims of the micro-studies has been to shed some light upon the various connections between external and internal types of migrations. We may, for instance, ask whether emigration and internal migration are alternative migrational phenomena. Do the in-migrants fill the vacant places left by the out-migrants? What is the relationship between short-distance and long-distance movements? Are earlier migrants more apt to emigrate than the more stationary part of the population? Are there any structural differences in the migratory streams as to the sex, age, and occupational composition of the migrants, etc. We shall return to some of these questions later in this survey. In the following pages I shall try briefly to outline some of the findings presented in the local studies regarding the changing volume and rhythm of emigration and internal migrations.

Reino Kero compares the fluctuations of migration within Toholampi with the tptal out- and in-migration of the commune. Graphically, the three curves behave much in the same way during the years 1870-83. In the rest of the 1880's both migration within the commune and in-migration decreased when out-migration increased, and vice versa. In other words, there was an opposite rhythm in total out-migration on the one hand, and total inmigration/migration within Toholampi on the other.

If we compare the different migrations from Toholampi, i.e. 
short-distance migration to the five neighbouring communes, longdistance migration to the rest of Finland, and emigration to America, it appears that long-distance migration and emigration on the whole were alternative migrational movements. Thus, in the peak years of emigration, $1873,1881-82$, and 1887, migration to other parts of Finland was clearly reduced, reaching a higher level when emigration was low. On the other hand, emigration and short-distance migration showed a high degree of co-variation (except in 1887). It is possible that emigration acted as a stimulus to short-distance movements, because a demand was created to fill the vacant places of labourers and servant maids who had left for America earlier in the spring the same year.

In-migration from the neighbouring communes fluctuated inversely with long-distance in-migration until the mid-1880's. Reemigration from America was too inconsiderable to be taken into account in the comparison. On the other hand, we observe here, as elsewhere, that the re-emigration curve lags some years behind the emigration curve. A comparison between long-distance movements from and to Toholampi indicates that these migrations fluctuated inversely until about 1885 , whereas the curves of migration to and from the adjacent communes traced about the same graphic pattern. Similarity of economic structure may have played a role in this context. On the whole, many factors must be considered when explaining why some migrational streams fluctuated inversely while others showed a high degree of co-variation: the pull from America, the start of industrialization and urbanization in Finland, the situation on the labour market both at home and in the receiving areas, "good" and "bad" times generally, etc.

In the Swedish district Alfta the emigration peak during 1881-85 coincided with increasing intensity also in the other migrational movements registered, and mostly so in migration within the parish. Emigration increased by $6 \%$ of the mean population relative to the preceding five-year period, and migration within the parish boundaries by $5.5 \%$. Generally speaking, geographic mobility became more pronounced both internally and externally.

We may here pertinently pose the question: did the increased internal mobility, as it were, fill the vacancies caused by the emigration? In the last five-year period, 1886-90, emigration was reduced by $2.7 \%$, while internal out-migration swelled by $3.2 \%$. Internal out-migration was thus becoming an alternative to emigration. Internal immigration, too, was growing towards the end of the 
Figure 4. Number of registered migrations in Alfta parish 1871-90. Percentage of mean population.

Source: Soderberg, figure 1, p. 8.

a) Internal and external migration
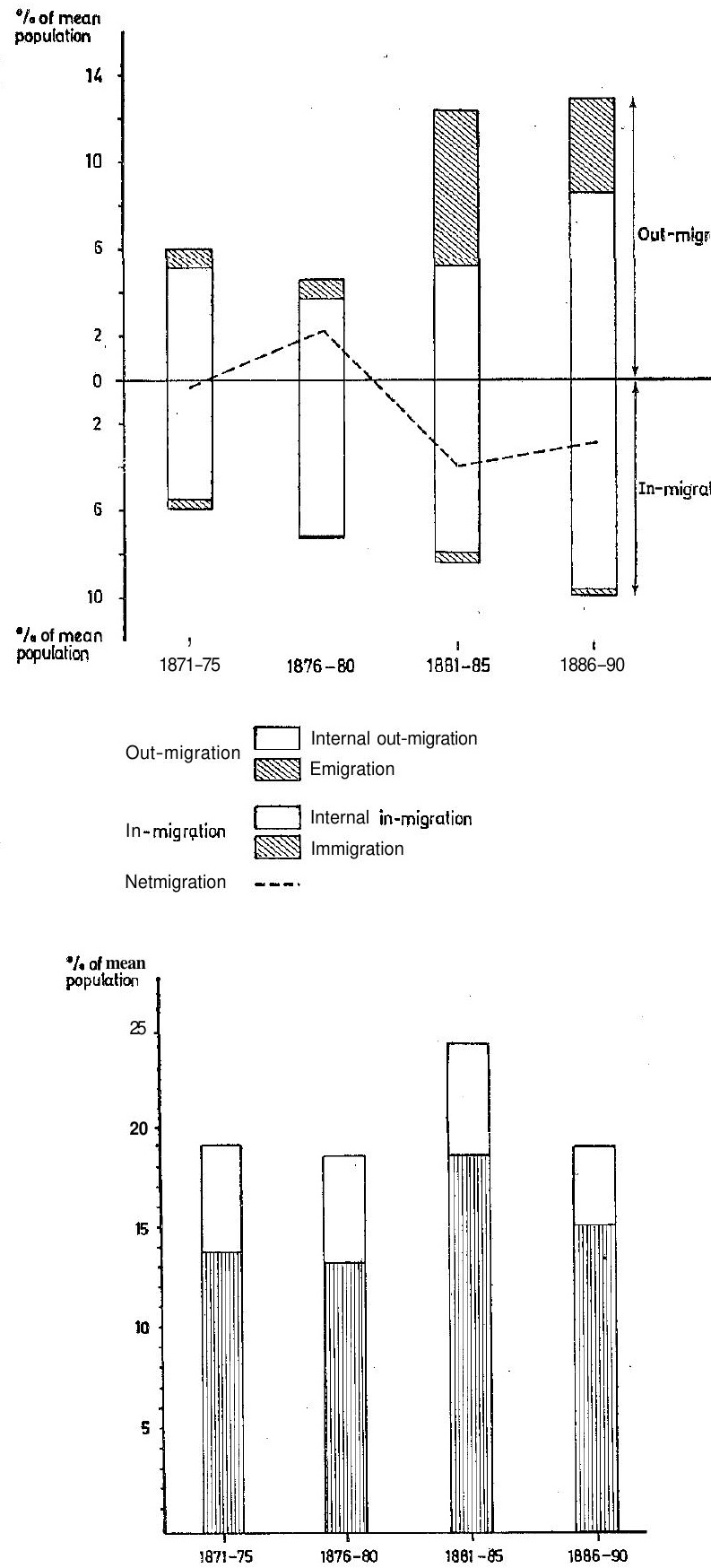

b) Total migration within the parish 
1880's. Net migration and emigration showed an inverse covariation (see Figure 4).

By means of the Swedish parish registers of catechetical examinations (husförhörslängder), which functioned as a kind of continuous population register, it is possible to classify a parish population in groups of stationary people, migrants within the commune, in- and out-migrants, emigrants, births and deaths by quinquennial periods.

Kjell Soderberg has analysed the catechetical registers of Alfta and shown that of the people living in the parish during 1871-90, two-thirds had been stationary during the respective five-year periods, about 10-11\% were born, $12-13 \%$ had moved within Alfta, and 3-5.8\% had migrated into the parish in the course of the preceding five years.

How then, were the internal out-migrants noted in the catechetical registers? The figures show that between 54.6\% (1886-90) and $64.7 \%(1871-75)$ had been stationary within the five-year periods until they left Alfta, and about one-fifthhad been registered as in-migrants. The proportion of in-migrants among the outmigrants rose to $29.7 \%$ in the years $1886-90$, whereas the proportion of those having moved within the parish fluctuated around 7-8\%.

Analysing the emigrants in the same way, Soderberg rather surprisingly found that fully $80 \%$ (four-fifths) had been stationary within the different quinquennial periods until their departure. Also, the emigrants had a considerably smaller proportion of inmigrants compared to the out-migrants, but a somewhat higher proportion of people having moved within the parish. As a group then, the emigrants had been markedly less mobile than the internal out-migrants. Admittedly, this mode of calculation is not altogether satisfactory. It seems nevertheless to be an established fact that the Alfta emigrants were less mobile before their departure than the other out-migrants from the same district.

As we have mentioned earlier, the Danish and the Norwegian material is much more incomplete than the Finnish and Swedish sources when it comes to describing and analysing internal migrations. The Norwegian case study of Ullensaker is almost exclusively concentrated on the emigration from this district; so we are not able at present, to say much about emigration compared to internal migrations affecting the parish. The most heavy emigration period in Ullensaker - 1865-1875 - coincided with the greatest net loss of people due to internal migration. The volume of both internal and external migrations was considerably reduced in the 1890 's. 
Table 13. Out-migrants, emigrants. Migration rates. Permille of Torslev mean population per 10-year period.

\begin{tabular}{lccc}
\hline Years & Town migrants & Skæve migrants & Emigrants \\
\hline $1870-1879$ & 51.8 & 33.6 & 24.2 \\
$1880-1889$ & 62.0 & 23.7 & 87.0 \\
$1890-1900$ & 76.3 & 36.7 & 42.2 \\
\hline $1870-1900$ & 236 & 127 & 156 \\
\hline
\end{tabular}

Source: Vangdrup, tab. 7, p. 14.

The Danish study of Torslev makes it possible to compare'the frequency of migrations to 7 towns, to the neighbouring parish Skzeve, and to America (Table 13).

On the whole, many more people found their way to the towns than to America. But-migration to the towns was constantly increasing, even in the 1880's when emigration reached a climax. Short-distance migration to Skzeve was reduced during the mass emigration in this decade, but both Skæve migration and town migration swelled in volume in the 1890's, when emigration was falling off. In spite of this, the total registered out-migration was reduced.

Vangdrup considers the short-distance migration to the parishes bordering on Torslev to be the most frequent of the migratory movements; in this study only one of five neighbouring parishes has been included. It seems possible that migration to the towns became an alternative to migration overseas towards the turn of the century. At the same time the stream of town migrants from Torslev was more directed towards the more distant destinations of Aalborg/N. Sundby.

In Vopnafjördur the connection between emigration and internal migration is dramatically illustrated in 1875-76. In 1875191 persons moved into the parish, but only 25 were out-migrants. The majority of the in-migrants were people who fled from their destroyed homes in the neighbouring district, after the catastrophic eruption of Dyngjufjöll. In the following year, 1876, the total number of out-migrants was 154; among them being 88 emigrants, of which 35 had moved to the parish the preceding year. 62 of the in-migrants of 1875 emigrated to America in the period 1876-80. Thus a volcanic eruption caused an unexpectedly great in-migration to Vopnafjordur, and the rootless refugees from this disaster seem to 


\section{Number}

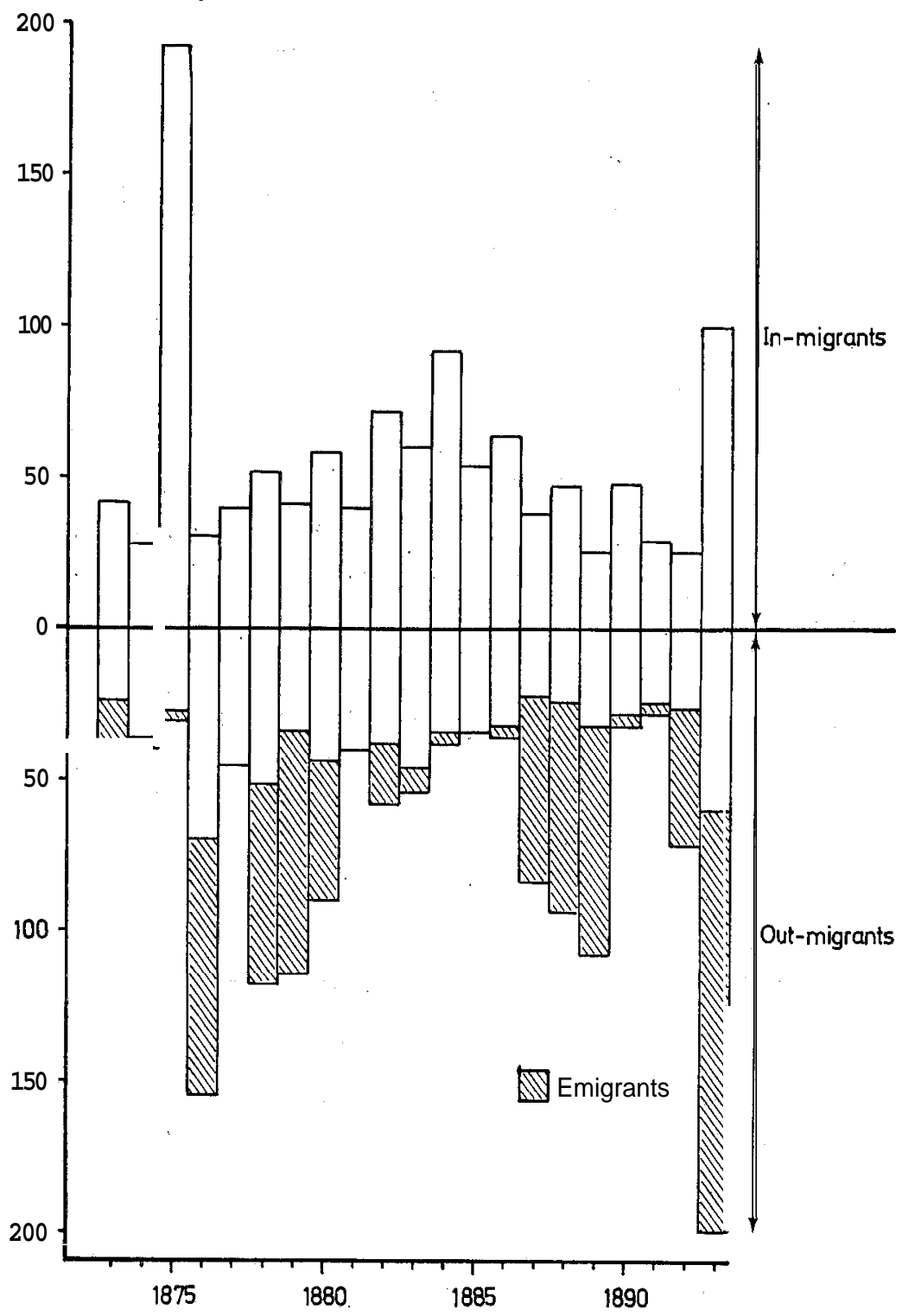

Figure 5. Migration in Vopnafjordur 1873-93.

Source: Kristinsson, figure III-7, p. 29. 
have acted as a kind of trigger mechanism on mass emigration from the area.

Except for the exceptional migration of 1875-76, there is no marked connection between the flow of internal and external migration, perhaps apart from 1893, when emigration culminated. In the same year the number of in-migrants increased three-fold in comparison with the preceding years, 1890-92. The number of internal out-migrants also rose.

Admittedly, there was an increased in-migration during the emigration pause of 1881-86 (see Figure 5) and in-migration was reduced in the emigration years of 1887-98. However, Júníus Kristinsson concludes that " . . .emigration seems largely to have been a net addition to the usual internal migration, having no sharp effects upon it". And, "the feasible idea that people migrated to Vopnafjördur to fill the gap left by large groups of emigrants is not borne out by the pear by year fluctuations, with the single exception of 1893 " (p. 30). In the Vopnafjördur study there is nothing to indicate that previous migrants were more prone to emigrate than the stationary population. "But the reverse seems rather to be the case. Vopnafjordur was in other words not to any appreciable extent an intermediate destination for emigrants by stages" (p. 28).

Emigration and the growth of population in the local village seem to have been complementary to each other. During the trough years of emigration from 1881 to 1886 the number of village inhabitants rose from ca. 50 to 109 , but during the mass emigration 1887-93 the net addition was only 14 persons. When emigration stopped, the village population increased to 203 in 1900. The emigration intensity of the village and the rest of the parish were about equal. Here again 1893 is an exception, when almost onethird of the village inhabitants emigrated (46 of 150 emigrants).

\section{Migration Structures}

The following chapter is an attempt to compare some of the results of the micro-studies pertaining to the distribution of emigrants/migrants according to sex, age, marriage and socio-occupational status.

\section{Sex Distribution}

Emigration from Toholampi was strongly male-dominated, as was the case in emigration from the rest of the country. Of the total 
population of the commune in the 1880's $48.9 \%$ were men and $51.1 \%$ women. In the same decade 466 emigrants left Toholampi, of whom $70.8 \%$ were men and only $29.2 \%$ women. Women were even more strongly under-represented in the entire Finnish emigration: $24.4 \%$ during the period 1878-90, compared with $31.4 \%$ among the Toholampi emigrants in the same period.

The emigrants of Alfta showed a much more even sex distribution. There were about 5\% more men than women during the emigration wave of 1881-85, whereas women had a slight majority in 1886-90.

Of 1683 emigrants from Ullensaker during the years 1867-99, $58.5 \%$ were men (984) and $41.5 \%$ women (699). It should be noted that the proportion of men was considerably greater in the initial phase of an emigration wave, for instance $68.5 \%$ in the years 1868 and 1880. The female proportion increased in the final phase of the wave. Some years had even a majority of women: 1872-73 and 1893. The Ullensaker emigration was strongly concentrated in two wave-like movements, 1868-72 and 1879-83, when 40.9 and $29.1 \%$, i.e. $70 \%$ of the emigrants, left the commune. The female emigration was more concentrated to the first-mentioned period than that of the men $(44.7 \%$ of the female emigrants left in $1868-72$, only $38.5 \%$ of the men). Generally speaking, emigration became more maledominated in the 1880's and 1890's.

Of the 340 registered Torslev emigrants between 1868 and 1899, $59.5 \%$ were men and $40.5 \%$ women (excluding children under 15 year* of age). This corresponds well with the Norwegian material from Ullensaker. However, rural emigration from all of Denmark was considerably more male-dominated in the same period: $64.8 \%$ men $-35.2 \%$ women.

In the first eight years, 1873-80,310 emigrants left Vopnafjördur, and among these there was a majority of women (166:144). Among 446 emigrants during 1881-93 thcrc was an approximate balance between women and men (225:221). Taken together, there was a surplus of 26 women during the 1873-93 period.

It is thus clear that the Finnish investigation area had the strongest male-dominated emigration $(70 \%)$, followed by the Danish and the Norwegian districts, with $59.5 \%$ and $58.5 \%$ men respectively. The sex distribution among the Alfta emigrants was practically in balance, while Vopnafjordur had a slight predominance of women among those who left for America.

In internal migrations women were generally more mobile than 
Table 14. Total mobility (incl. migration within the commune) in Toholampi. Permille of mean population.

\begin{tabular}{|c|c|c|}
\hline & $1870-1879$ & $1880-1889$ \\
\hline Women & 48,0 & 91,7 \\
\hline Men & 39,0 & 77,5 \\
\hline
\end{tabular}

Source: Kero, p. 42.

men (Table 14). In the total migration of Toholampi there were about $44 \%$ men and $56 \%$ women during the whole period. But the various migrational streams differed rather markedly as to sex distribution. Migration within the commune and short-distance migration to the neighbouring communes had a clear female majority, 60-65\%. In long-distance movements to other parts of Finland the sexes were evenly balanced, whereas emigration, as we have seen, was heavily male-dominated. The in-migrations from the different areas resembled the corresponding out-migrations regarding sex distribution. Re-emigration from America was particularly a male phenomenon ( 70 of 85 re-emigrants in the 1880's were men).

The Toholampi material thus supports the hypothesis that women generally moved more often than men, above all in short-distance migration. Long-distance migration seems to be more preferred by men. However, this is not always the case, as may be demonstrated by the sex composition of emigration from Vopnafjordur.

It is interesting to note that a great part of the higher mobility among women was due to marriage. Counting migrants within Toholampi and internal out-migrants from the commune in 187079 according to sex distribution, we observe that women made 151 more moves than men. However, as many as 143 of these migrations came about because of marriage. The corresponding figures for the 1880's were 248 and 117.

It is commonly assumed that there was a preponderance of women in the migration to cities and urban areas. This is in part corroborated by the Torslev sample. However, as we see in Table 15 , there was a balance in the sex distribution among the townmigrants around 1900. And there was, in fact, a majority of men among the Torslev-born in the towns of Skagen and Fredrikshavn. Vangdrup maintains that this was caused by the one-sidedness of the labour market in these towns, where fishing was the main industry. Thus one should bear in mind the importance of job 
Table 15. Sex distribution. Torslev out-migrants over 14 years of age, 1870-1901.

\begin{tabular}{lcc} 
& Men & Women \\
\hline To the towns & $48.3 \%$ & $51.7 \%$ \\
To Skæve & $50.9 \%$ & $49.1 \%$ \\
To the towns ca. 1900 & $50.0 \%$ & $50.0 \%$ \\
\hline
\end{tabular}

Source: Vangdrup, p. 16.

opportunities in the receiving area when studying the sex composition of internal migrations.

Elisabeth Koren has compared the age pyramids of the Ullensaker population in 1865,1875 and 1891, and has tried to calculate how much of the reduction within the different age groups could be ascribed to the emigration from the district.

In the decade 1865-75 there was a numerical decline in all age groups, with the greatest loss of people within the 15-30 year-old bracket. But the emigrants constituted a smaller proportion of the net reduction of this age group than among the 0-14 and 30-49 year-olds. This can be explained by the fact that emigration at that time was a typical family emigration. Koren assumes that 15-30 year-olds to a greater extent participated in the internal outmigration from the parish than in emigration overseas. This point has not, however, been examined more closely.

In 1891 the net reduction of the number of the 15-30 year-olds of 1875 was 411 men and 337 women. Koren concludes that "for the men emigration was the most popular solution; about twothirds of the reduction is explained by the number of emigrants. The women left the parish, but not the country; only one-third of the net reduction can be explained by emigration" (p. 6). This is, of course, an overstatement.

This study of the age pyramids indicates that emigration changed character from being initially a family emigration, with a high proportion of children and persons over 30 years of age, to becoming increasingly a male-dominated emigration of youths towards the end of the period 1867-99.

For the time being we have, unfortunately, very few statistics showing the sex and age distribution of internal out-migrants from Ullensaker after 1865, and so we cannot make any real comparison in this respect with the emigration structure. It would be especially interesting on this point to compare emigration with out-migration to Christiania during 1865-1900. It is remarkable that of the 411 
persons born in Ullensaker and registered in Christiania 1865, 227 were males and 184 females. This male majority in a town-directed migration may be explained by the labour market of the capital city. (Langholm, op. cit., pp. 60-61). According to an unfinished study by Trond Vatne, about $50 \%$ of the 921 Ullensaker-born living in Christiania in 1875 were males. On the other hand, there was a female majority among the out-migrants to the neighbouring parishes $-58 \%$ in 1865 .

\section{Age Distribution}

It is a well-known fact that the age structure of a migrant population differs widely from that of a resident or stationary population. We may exemplify this both as regards emigration and internal migration, by comparing some results from the local studies treated here.

Generally, the age group 15-30 is most strongly over-represented in the migrational streams compared with the resident population. Thus $61.3 \%$ of those who moved within Toholampi commune in the 1880 's were people aged $15-34$, while only $27.6 \%$ of the total population belonged to the same age group. Table 16 shows that emigration was by far the most selective in respect of age. As many as $63 \%$ of 466 emigrants from Toholampi during 1880-89 could be found in the 15-29 year-old bracket, which is relatively three times as many as in the total population. In all migrations the 15-19 year-olds constituted the greatest five-year group, especially in emigration and migration within the commune (26.8\%). The considerably smaller representation of persons aged 15-19 among long-distance migrants to other parts of Finland is explained by the fact that this migration had a greater proportion of children 0-14 and adults 30-34 years old. To some extent this was also true for short-distance migration to the neighbouring communes.

Table 16. Age distribution among Toholampi migrants. 15-29 years old, 18801889. Percentages. Source: Kero, appendix 8b.

\begin{tabular}{cccccc}
\hline $\begin{array}{c}\text { Age } \\
\text { groups }\end{array}$ & $\begin{array}{c}\text { Mean } \\
\text { popula- } \\
\text { tion }\end{array}$ & $\begin{array}{c}\text { Migrants } \\
\text { within } \\
\text { Toholampi }\end{array}$ & $\begin{array}{c}\text { To } \\
\text { neighbouring } \\
\text { communes }\end{array}$ & $\begin{array}{c}\text { To other } \\
\text { parts of } \\
\text { Finland }\end{array}$ & $\begin{array}{c}\text { To } \\
\text { America }\end{array}$ \\
\hline $15-19$ & 9.2 & 26.8 & 20.3 & 17.3 & 26.8 \\
$20-24$ & 6.3 & 16.4 & 19.5 & 13.7 & 22.5 \\
$25-29$ & 5.9 & 10.5 & 11.0 & 10.6 & 13.7 \\
\hline $15-29$ & 21.4 & 53.7 & 50.8 & 41.6 & 63.0 \\
\hline
\end{tabular}


Reino Kero has.calculated annual age specific migration intensity (per 1000 persons in various age groups). The total migration frequency (all registered migrations included) was greatest in the age group 20-24 $(236.2 \%)$, followed by the 15-19 year-olds $(229.0 \%)$. In the total out-migration, migration intensity was heaviest among persons 20-24 years of age, especially among the emigrants $(60.3 \%)$, whereas migration within the commune was by far the most intense among the 15-19 year-olds. These figures refer to the 1880 's.

The AID-analysis of the Alfta migration during the two periods 1881-85 and 1886-90 showed that the age variable had the greatest explanatory value when it came to characterize emigrants/outmigrants versus the stationary population. The highest mobility was decisively within the age groups 20-34, 15-19, and 35-44. There was a clear shift towards younger age groups. In the 1870 's persons aged 25-29 years had the highest mobility, whereas in the 1880's the 20-24 year-olds constituted the most mobile group, according to the Alfta material (see Figure 6).

$48.8 \%$ of the Ullensaker emigrants belonged to the most mobile age group, 15-29. The largest five-year group was 20-24, it represented alone over one-fifth of all emigrants from Ullensaker (Table

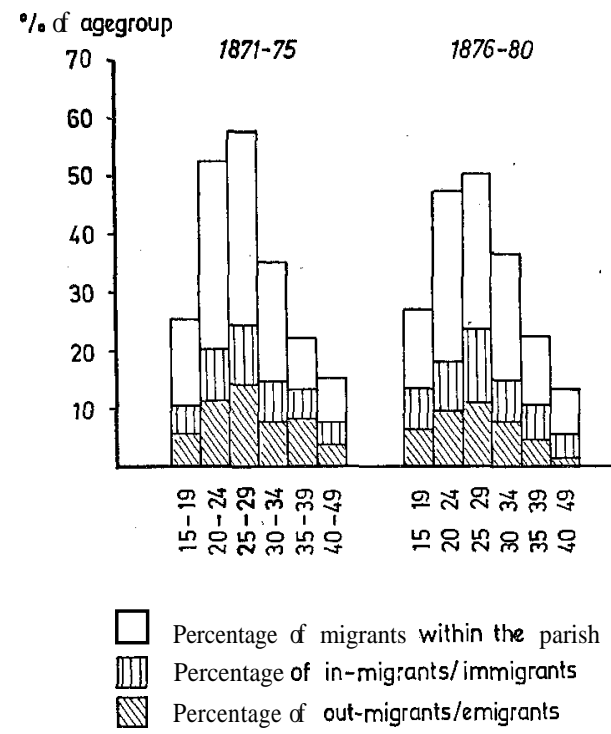

Figure 6. Total mobility and proportions of out-migrants/emigrants and inmigrants/immigrants in six age groups by five-year periods. Alfta 1871-90.

Source: Soderberg, figure 8, p. 40. 
Table 17. Age distribution. Ullensaker emigrants 1867-1899.

\begin{tabular}{rcccc}
\hline Age & Number & $\%$ & Men \% & Women $\%$ \\
\hline $0-14$ & 457 & 27.7 & & \\
$15-19$ & 235 & 14.0 & & \\
$20-24$ & 365 & 21.7 & 24.7 & 17.5 \\
$25-29$ & 221 & 13.1 & & \\
\hline $15-29$ & 821 & 48.8 & 53.3 & 42.4 \\
\hline
\end{tabular}

Source: Koren, p. 9.

Table 18. Emigration of young people (age group 15-29) from Ullensaker and their proportion of the total population. Percentages.

\begin{tabular}{llccc}
\hline & & Men & Women & Total \\
\hline Census & 1865 & 22.7 & 23.4 & 22.7 \\
Emigrants & $1868-73$ & 37.0 & 25.0 & 31.0 \\
Census & 1875 & 27.0 & 26.0 & 28.3 \\
Emigrants & $1879-83$ & 61.0 & 44.0 & 56.0 \\
Census & 1891 & 25.1 & 23.4 & 26.6 \\
Emigrants & $1892-93$ & 72.0 & 57.0 & 70.0 \\
\hline
\end{tabular}

Source: Koren, tab. 7, p. 10.

17). But within this age group there was a marked difference between men and women. Almost one-fourth of the male emigrants were 20-24 years old, but only $17.5 \%$ of the females.

The long-term change towards a more pronounced youth emigration is illustrated by Table 18 .

These figures are very illustrative of the increasing proportion of younger people among the emigrants. They also serve to point out the development towards a more unbalanced sex distribution. There was an increasing over-representation of the age group 15-29 compared to the total population of the district. This was especially prevalent among the male emigrants. Nevertheless, there were relatively fewer women than men aged 15-29 Ieft in Ullensaker according to the census of 1891 . The reduction of the population (ca. 2000 people 1865-91) was caused by a large net migration Ioss, but the young women obviously chose destinations within the country to a greater extent than the young men.

The main lines of the age distribution of the Danish Torslev migrants are shown in Table 19. In Torslev, too, the emigrants were most heavily concentrated in the age group 15-29, more so 
Table 19. Torslev migrants by age. Percentages.

\begin{tabular}{lccc}
\hline Age groups & $\begin{array}{c}\text { Town migrants } \\
(1901)\end{array}$ & $\begin{array}{c}\text { Skæve migrants } \\
(1901)\end{array}$ & $\begin{array}{c}\text { Emigrants } \\
1868-99\end{array}$ \\
\hline $0-14$ & 20.7 & 29.6 & 24.5 \\
$15-29$ & 54.3 & 34.8 & 60.4 \\
$30-49$ & 21.5 & 27.4 & 10.4 \\
over 50 & 3.5 & 8.1 & 4.7 \\
\hline & 100 & 100 & 100 \\
\hline
\end{tabular}

Source: Vangdrup, tab. 8, p. 15.

than among emigrants from all rural districts in Denmark (55\%). Among the short-distance migrants to Skæve there were relatively more children and more people in the older age groups. It is a surprising fact that migrants to the towns had a smaller proportion of children than the emigrants, although the latter had only half as many in the age bracket $30-49(10.4 \%)$ as the former $(21.5 \%)$. This was probably due to a greater percentage of married persons with children in the age groups up to 29 years among the emigrants. In any case, Vangdrup has shown that the average emigrant wife of Torslev travelled with 2.4 children, while the average migrant wife going to a town only had 1.7 children.

According to Júníus Kristinsson's study the age distribution of the Vopnafjordur migrants was as seen in Tables 20 and 21.

Compared to the age structure of the total population in 1870 , the age groups 0-5, 21-35 and 51-60 were over-represented among the emigrants. On the other hand, the age groups 6-20 and 36-45 were under-represented. It will be seen that only $31 \%$ of the Vopnafjordur emigrants were 16-30 years old, whereas the corresponding percentages in the Toholampi, Ullensaker, and Torslev material were $63.0,48.8$, and $60.4 \%$ respectively (15-29). Relatively, there were thus twice as many young people in the Finnish sample as in the Icelandic. Vopnafjordur had a greater proportion of emigrants aged 31-35 and more children among the emigrants than the other investigation areas. This is indicative of a very extensive family emigration from the Icelandic parish. In addition, the Vopnafjordur study points at what may be called a threegeneration emigration pattern, considering the surprisingly large representation of older people; about $8.5 \%$ of the $1873-93$ emigrants belonged to the age group 51-60, but only $2.6 \%$ of the total population in 1870. Among the adult emigrants, the 21-25 and the 26-30 
Table 20. Internal migrants in Vopnafjördur by age 1821-1872, 1873-1893.

\begin{tabular}{lllll}
\hline & \multicolumn{3}{c}{$1821-72$} & \multicolumn{3}{c}{$1873-93$} \\
Age & $(\mathrm{N})$ & $\%$ & $(\mathrm{~N})$ & $\%$ \\
\hline In-migrants & & & & \\
$0-15$ & 346 & 26,2 & 279 & 26,1 \\
$16-30$ & 587 & 44,4 & 462 & 43,3 \\
$31-$ & 390 & 29,4 & 326 & 30,6 \\
\hline Total & 1323 & 100 & 1067 & 100 \\
Out-migrants & & & & \\
$0-15$ & 294 & 25,6 & 154 & 20,5 \\
$16-30$ & 527 & 46,0 & 368 & 49,1 \\
$31-$ & 326 & 28,4 & 228 & 30,4 \\
\hline Total & 1147 & 100 & 750 & 100 \\
\hline
\end{tabular}

Source: Kristinsson, tab. III-4, p. 31.

Table 21. Emigrants from Vopnafjördur 1873-93 by age.

\begin{tabular}{ccc}
\hline Age & Number & $\%$ \\
\hline $0-15$ & 280 & 37.0 \\
$16-30$ & 234 & 31.0 \\
$31-$ & 242 & 32.0 \\
\hline Total & 756 & 100.0 \\
\hline
\end{tabular}

Source: Kristinsson, tab. III-5, p. 31.

year-olds were the most numerous in the periods 1873-80 and 1881-93 respectively. This shift towards a somewhat older age group is also rather remarkable.

Age distribution among the internal migrants of Vopnafjordur differed from that of the emigrants in that the proportion of children was considerably smaller, and persons aged 16-30 were more heavily represented. Thus one-fifth of the internal out-migrants during the period 1873-93 were children, and almost one-half were young people in the 16-30 year-old bracket. Of the emigrants $37 \%$ were children and $31 \%$ were young people.

Family migration

The proportion of children in the various migrational streams illustrates the extent of family emigration. According to Table 22, the emigration from Vopnafjordur was the movement most marked 
Table 22. Percentages of children among migrants. (0-14 or 0-15 years).

\begin{tabular}{|c|c|c|c|c|c|}
\hline \multicolumn{3}{|l|}{ Emigration: } & \multicolumn{3}{|c|}{ Long-distance migration: } \\
\hline \multirow[t]{3}{*}{ From Toholampi } & $1870-79$ & 6.4 & From Tohol & ther parts & \\
\hline & $1880-89$ & 8.4 & Finland & $1870-79$ & 25.9 \\
\hline & & & & $1880-89$ & 26.7 \\
\hline \multirow[t]{3}{*}{ From Ullensaker } & $1868-72$ & 40.8 & & & \\
\hline & $1879-83$ & 22.6 & \multirow{2}{*}{\multicolumn{2}{|c|}{$\begin{array}{l}\text { From Torslev to } \\
\text { seven towns (1901) }\end{array}$}} & \\
\hline & 1867-99 & 27.7 & & & 20.7 \\
\hline \multirow{3}{*}{$\begin{array}{l}\text { From Torslev } \\
\text { From Vopnafjordur }\end{array}$} & $1868-99$ & 24.5 & \multicolumn{3}{|c|}{ Migration within the commune: } \\
\hline & $1873-80$ & 35.2 & \multirow[t]{2}{*}{ Toholampi } & $1870-79$ & 27.7 \\
\hline & $1881-93$ & 36.4 & & $1880-89$ & 19.3 \\
\hline \multicolumn{6}{|c|}{ Short-distance migration : } \\
\hline \multirow{2}{*}{\multicolumn{4}{|c|}{ From Toholampi to five neighbouring communes }} & $1870-79$ & 22.3 \\
\hline & & & & $1880-89$ & 24.8 \\
\hline \multicolumn{4}{|c|}{ From Torslev to Skeve (1901) } & & 29.6 \\
\hline
\end{tabular}

Source: Kero, appendix 8a-b, Koren, pp. 9-10, Vangdrup, p. 15, and Kristinsson, pp. 18-20.

by family emigration. About $36 \%$ of all emigrants from this district were 0-15 years old. Kristinsson found that over $70 \%$ of the total emigration could be characterized as family emigration.

In Ullensaker, too, family emigration was strong, especially during the first emigration wave that took place from 1868 to 1872 . But the proportion of children was reduced by about $50 \%$ towards the end of the 19th century. The Torslev emigration had also a considerable family representation. On the other hand, it seems that families constituted a very moderate share of the Toholampi emigration (between 6.4 and $8.4 \%$ were children aged $0-15$ ).

Family migration was, moreover, marked in the registered shortand long-distance internal migrations from Toholampi and Torslev. On the whole it seems that the town migrants from Torslev had the smallest proportion of children in the $0-14$ year bracket $(20.7 \%)$. In the migration within Toholampi commune the proportion of children was reduced from $27.7 \%$ in $1870-79$ to $19.3 \%$ in $1880-89$. However, in the 1880's the family groups represented almost $60 \%$ of all those who moved to other parts of Finland, and more than $50 \%$ of the migrants to the five neighbouring communes. The corresponding in-migrant streams resembled the out-going streams regarding family representation. In the total out-migration from Toholampi the family proportion increased from $26.3 \%$ in $1870-79$ to $40.8 \%$ in $1880-89$. 
Table 23. Emigrant families from Ullensaker 1867-84.

\begin{tabular}{|c|c|c|c|c|}
\hline $\begin{array}{c}\text { Father's } \\
\text { occupation }\end{array}$ & $\begin{array}{c}\text { Families } \\
1867-75 \\
\mathrm{~N} \%\end{array}$ & $\begin{array}{l}\text { Average no. } \\
\text { of children } \\
\text { per family }\end{array}$ & $\begin{array}{c}\text { Families } \\
1876-84 \\
\mathrm{~N} \%\end{array}$ & $\begin{array}{l}\text { Average no. } \\
\text { of children } \\
\text { per family }\end{array}$ \\
\hline Farmer & $30 \quad 33,3$ & 4,1 & $4 \quad 12,5$ & 1,5 \\
\hline Cottager & $25 \quad 27,8$ & 3,5 & 6,2 & 3,5 \\
\hline Craftsman & $10 \quad 11,1$ & 3,3 & 3,1 & 1,0 \\
\hline Worker & $25 \quad 27,8$ & 2,4 & $25 \quad 78,2$ & 3,1 \\
\hline Sum & 90100 & 3,1 & $32 \quad 100$ & 2,8 \\
\hline
\end{tabular}

Source: Koren, tab. 10, p. 13.

Elisabeth Koren has analysed the social background and the number of children of 122 reconstructed emigrant families from Ullensaker 1867-84 (Table 23).

Family emigration among farmers and cottagers (husmenn) was concentrated to the period 1867-75. The farmers generally brought with them more children per family than the cottagers. We have, however, reason to believe that so-called "scattered" family emigration was more common in the cottager class. It was easier to finance the travelling expenses when the emigration of several family members was spread over some years. This meant that family groups would be split up, and then later on become reunited in America. The most usual pattern was perhaps that the husband went over first, to be followed by his wife and children a couple of years later. Scattered emigration of brothers and sisters was common among the young unmarried people.

The worker families (chiefly landless agricultural labourers) were evenly distributed over the two periods. But it was observed that the fathers in the worker families were younger and had fewer children in 1867-75 than in 1876-84.

In my own work on the emigration from Tinn in Upper Telemark from $1837-1907$, I found that $80 \%$ of the early emigration (183743) was made up of families. This proportion was reduced to about $40 \%$ at the end of the period studied, 1891-1907.4 In a similar study on the emigration from Dovre in Northern Gudbrandsdal, Arnfinn Engen has shown that $50 \%$ of the emigrants travelled in groups on a joint ticket during 1866-1914. He also found that $50 \%$ of the emigrants had close relatives in America. ${ }^{5}$ 


$\begin{array}{ll}\text { Re-emigrants : } & 67,1 \\ \text { Emigrants : } & 41,4 \\ \text { Long-distance migrants : } & 26,3 \\ \text { Short-distance migrants : } & 24,9 \\ \text { Migrants within the commune: } & 21,0\end{array}$

Source: Kero, pp. 49-50.

\section{Marital status}

The difierent studies presented here do not permit many cornparisons on this point. I shall therefore only briefly mention some results regarding the civil status of the migrants.

In the 1880 's, $36.4 \%$ of the Toholampi population were married, and according to the figures in Table 24, it seems that the proportion of married people increased with the migration distance. I would draw your attention to the relatively high proportion of married emigrants. This is rather unexpected when we recall that among persons going to America the number of children was very limited. Apparently it was above all the newly-wed and couples with few children who emigrated from Toholampi. In Torslev, however, the average emigrant wife had as many as 4.1 children.

About $20 \%$ of the Ullensaker emigrants were married persons, but here we lack information on the marital status of $31 \%$ of those who went to America. There was a higher percentage of married persons among women than among men: 24.5 and $16.5 \%$. If we calculate the proportion of married persons among adult emigrants (over 15 years of age), we get $27.1 \%$. The proportion of married persons was, of course, greater in the period 1867-75, when family emigration was most pronounced, about $33.5 \%$.

A combination of age and marriage statistics shows that in the period 1867-75 two-thirds of the married emigrants from Ullensaker belonged to the age group 30-49 years. In the period 1876-99 twothirds of the married emigrants were 20-39 years old. This means that the younger couples increasingly became over-represented among the emigrants. 38.2\% of the married emigrants in 1876-99 were aged 20-29, while the corresponding percentage in the total Ullensaker population of 1865 was only 7.7. A special study revealed that the emigrating couples were $2 \frac{1}{2}$ years younger on an average at the time of marriage, compared with the average couple in Ullensaker. The emigrating farmer couples were particularly young 
when marrying, compared with the average couple of their social class (4-5 years younger).

Detailed information about 23 couples who emigrated during the 1867-75 period clearly showed that emigration for these people was a realistic alternative, both economically and socially. The future prospects at home were very dim indeed for these young, newly-wed persons.

\section{Occupational/Social Distribution}

What was the social and occupational background of the migrants? What social strata did, in particular, feed the migrational streams? This is a central problem in migration research. However, it must be admitted that a comparative approach on an international level is very complicated in this respect. For instance, the occu-

Table 25. Migration in and from Toholampi 1880-89. Percentages of the most important occupational groups.

\begin{tabular}{lcccccc}
\hline Group & $\begin{array}{c}\text { Migration } \\
\text { within the } \\
\text { commune }\end{array}$ & $\begin{array}{c}\text { To the } \\
\text { neighbour- } \\
\text { ing } \\
\text { communes }\end{array}$ & $\begin{array}{c}\text { To other } \\
\text { parts of } \\
\text { Finland }\end{array}$ & $\begin{array}{c}\text { Emigra- } \\
\text { tion }\end{array}$ & $\begin{array}{c}\text { Total } \\
\text { Toportion } \\
\text { population }\end{array}$ \\
\hline Farmers & 22,7 & 39,0 & 33,1 & 52,1 & 31,6 & 56,4 \\
Tenants & 4,9 & 3,2 & 3,2 & 4,7 & 4,5 & 6,6 \\
Cottagers & 6,4 & 9,2 & 3,9 & 6,7 & 6,4 & 8,0 \\
Hired help & 61,2 & 45,8 & 53,4 & 33,3 & 53,0 & 21,2 \\
\hline Total abs. & 1336 & 249 & 281 & 466 & 2332 & 2748 \\
number & 136 & & & & & \\
\hline
\end{tabular}

Source: Kero, pp. 44-45 and appendix 6e.

Table 26. Migration intensity among farmers, hired help etc. in Toholampi. Yearly average per 1000 persons in the group, 1880-89.

\begin{tabular}{lccccc}
\hline \multicolumn{1}{c}{$\begin{array}{c}\text { To the } \\
\text { Migration } \\
\text { within the } \\
\text { commune }\end{array}$} & $\begin{array}{c}\text { neighbour- } \\
\text { ing } \\
\text { communes }\end{array}$ & $\begin{array}{c}\text { To other } \\
\text { parts of } \\
\text { Finland }\end{array}$ & $\begin{array}{c}\text { To } \\
\text { America }\end{array}$ & Total \\
\hline Farmers & 19.5 & 6.3 & 6.0 & 15.7 & 47.5 \\
Hired help & 140.1 & 19.6 & 25.7 & 26.7 & 212.0 \\
Cottagers & 38.5 & 10.4 & 5.0 & 14.0 & 67.9 \\
Tenants & 36.7 & 4.4 & 5.0 & 12.2 & 58.3 \\
\hline
\end{tabular}

Source: Kero, pp. 58-59 and appendix 8. 
pational/social categories and the source material of the Nordic countries vary so much that a comparison of this aspect of migration structure must of necessity be crude and approximate, showing some main lines in the recruitment of the migrant masses.

Other groups than those listed in Tables 25 and 26 represented negligible quantities in the migrations, apart from public officials, who made up $2.8 \%$ of the long-distance migration to other parts of Finland.

The farmer class had a majority of the emigrants $(52 \%)$ but had its smallest proportion of the migration within the commune (well over one-fifth). Relatively then, there were twice as many farmers among the emigrants. The absolutely largest group that migrated was the hired help (agricultural labourers and servant maids). They held an overwhelming majority in migration within the commune $(61.2 \%)$, but constituted only one-third of the emigrants. The category here called hired help is strongly over-represented in all migrations in relation to its strength in the total population of Toholampi in the decade 1880-89. The cottagers had only a slight over-representation in migration to the neighbouring communes. As we would expect, the farmers were under-represented in all migrations, but not so much in emigration, where they had a surprisingly high proportion. There were undoubtedly problems in raising the money for the America ticket among those belonging to the lowest and poorest groups in the rural community.

There was a great increase in migration frequency within the commune from the 1870's to the 1880's, and this was due, above all, to a greater migration inclination among the farm hands and the servant maids (from 51.5 to $140.1 \%$ yearly), while migration intensity within the commune was on the same level in the two decades among the farmers. The emigration movement was inconsiderable in the 1870's. During the mass emigration of 1880-89, emigration intensity in the farmer class was over twice as strong as farmers' migration intensity to the neighbouring communes and to other parts of Finland. Even so, the servant class (hired help) was, relative to its strength in the population, more severely drained by emigration and, moreover, about an equal number of the hired help class migrated to other parts of Finland. Cottagers and tenants moved more often within the commune than the farmers, and they too had a fairly strong emigration intensity (see Table 26).

It seems natural that the young, unmarried people who constituted the great bulk of the servant class should have the highest 
'Table 27. Geographic mobility in various occupational groups in Alfta 1881-85. Percentages of number (N)-excl. births and deaths - in each group.

\begin{tabular}{|c|c|c|c|c|c|}
\hline Occupation & $\begin{array}{l}\text { Migration } \\
\text { within the } \\
\text { parish }\end{array}$ & $\begin{array}{l}\text { Internal } \\
\text { migration }\end{array}$ & $\begin{array}{l}\text { External } \\
\text { migration }\end{array}$ & $\begin{array}{c}\text { Total } \\
\text { mobility }\end{array}$ & $\mathrm{N}$ \\
\hline A Farmers & 18.6 & 7.2 & 1.8 & 27.5 & 1307 \\
\hline Crofters (torpare) & 6.1 & 6.1 & 4.1 & 16.4 & 244 \\
\hline Soldiers & 13.5 & 2.9 & 4.5 & 21.0 & 377 \\
\hline $\begin{array}{l}\text { Farm hands } \\
\text { (drangar) }\end{array}$ & 52.9 & 10.8 & 13.7 & 77.5 & 102 \\
\hline $\begin{array}{l}\text { Servant maids } \\
\text { (pigor) }\end{array}$ & 50.9 & 30.2 & 9.5 & 90.5 & 222 \\
\hline labourers) & 23.0 & 17.8 & 13.7 & 54.5 & 422 \\
\hline Cottagers (husman) & 11.0 & 4.2 & 7.0 & 22.2 & 643 \\
\hline Merchants & 23.3 & 28.7 & 6.8 & 58.9 & 73 \\
\hline $\begin{array}{l}\text { Handicraftsmen } \\
\text { Public officials/ }\end{array}$ & 12.7 & 19.2 & 10.3 & 42.3 & 291 \\
\hline civil servants & 5.6 & 46.8 & 0 & 52.4 & 124 \\
\hline \multicolumn{6}{|l|}{$\begin{array}{l}\mathrm{B} \text { Sons/daughters } \\
\text { living at home: }\end{array}$} \\
\hline of farmers & 20.3 & 9.6 & 14.8 & 44.7 & 311 \\
\hline " crofters & 17.5 & 6.3 & 18.1 & 41.9 & 160 \\
\hline $\begin{array}{l}\text {,, hired help } \\
\text {, workers }\end{array}$ & 16.1 & 21.0 & 8.1 & 45.2 & 62 \\
\hline $\begin{array}{l}\text { cottagers } \\
\text { merchants/ } \\
\text { handicrafts- } \\
\text { men }\end{array}$ & 20.4 & 15.0 & 11.6 & 47.0 & 147 \\
\hline , public officials & 17.6 & 32.4 & $\begin{array}{l}0.1 \\
3.0\end{array}$ & 53.1 & 34 \\
\hline \multicolumn{6}{|l|}{$\begin{array}{c}\text { C Relatives "living- } \\
\text { in" (inneboende } \\
\text { slaktingar): }\end{array}$} \\
\hline with farmers & 15.3 & 10.6 & 4.7 & 30.7 & 85 \\
\hline , crofters & 24.1 & 0 & 22.4 & 46.5 & 58 \\
\hline $\begin{array}{l}\text { workers/ } \\
\text { cottagers }\end{array}$ & 10.3 & 10.3 & 6.9 & 27.5 & 58 \\
\hline $\begin{array}{l}\text { 'Other people "living- } \\
\text { in. (inhyses) }\end{array}$ & 32.4 & 2.7 & 5.4 & 40.6 & 37 \\
\hline
\end{tabular}

:Source: Soderberg, tab. 17. 
migration intensity. On the other hand, the handicraftsmen of Toholampi had a low migration frequency, but numerically this was a very small group (about 50 persons).

The AID-analysis of the Alfta material revealed that occupational status and age were the most important explanatory factors behind emigration/internal out-migration, in the 1870's and 1880's respectively. The most mobile groups concerning emigration/internal migration were the servants (drangar, pigor), landless labourers, and handicraftsmen. Tradesmen and public officials also frequently moved, but these were small groups. The lowest migration intensity was found among farmers, crofters, cottagers (torpare, husman), and soldiers.

However, one of the main sources of emigration consisted of the sons and daughters of farmers and crofters, together with servants, labourers and craftsmen. The farmers themselves moved to a greater extent within the parish than out of it. But generally, migration within the commune and emigrationlout-migration were dominated by the same social/occupational groups. Over $50 \%$ of the farm hands and the servant maids moved within the commune during 1881-85. In the internal migration the servant maids were much more strongly represented.than the farm hands (compare Ullensaker). The total mobility was about $90 \%$ among the servant maids and about $77 \%$ among the farm hands during the five years from 1881 to 1885 (see Table 27).

The occupational distribution of Norwegian emigrants is very imperfectly covered by the emigrant protocol material, as the number of persons for whom we lack information is great, especially regarding the females. If we count only adult male emigrants from Ullensaker during 1867-99, this number is reduced from $46.5 \%$ to $8.3 \%$ (62 of 748 persons) (Table 28).

Apart from the "unknown", other groups constituted only $3.7 \%$ of the male emigrants over 15 years of age. The workers, i.e. chiefly agricultural labourers, servants etc., were in an overwhelming majority among the emigrants. Craftsmen were the next largest group. The farmer and the cottager proportions were greater during the period $1867-75: 16.0$ and $6.4 \%$ respectively. The emigration of craftsmen was strongest in 1876-84 (18.3\%). The same was true of the worker emigration $(72.5 \%)$.

The emigration of workers and craftsmen was largely an emigration of young unmarried people, or people with small families. About $70 \%$ of these emigrants were 15-29 years old, but the workers 
Table 28. Occupational groups. Male emigrants from Ullensaker over 15 years old, 1867-99.

\begin{tabular}{lcr}
\hline & Number & $\%$ \\
\hline Farmers/farmer sons & 73 & 9.7 \\
Cottagers/cottager sons & 28 & 3.7 \\
Craftsmen & 107 & 14.3 \\
Workers & 450 & 60.2 \\
\hline Sum & 658 & 87.9 \\
Unknown & 62 & 8.3 \\
\hline
\end{tabular}

Source: Koren, tab. 13, p. 18.

were most heavily represented in the age group 20-24 years whereas there were most craftsmen among the 25-29 year-olds. Most of the farmers and cottagers were over 30 years old, the cottagers in particular being somewhat older.

The term "worker" is rather confusing. E. Koren has made a closer study of the social background of 147 (of 315) worker emigrants 1867-84, who have been traced in the census material of 1865 and 1875. Of this sample, 65 were found to be farmers/ farmer sons, 36 cottagers/cottager sons, 12 craftsmen and only 34 were originally workers/servants. Admittedly, this sample is not altogether satisfactory, but it seems clear that worker emigration was largely recruited from the farmer and the cottager classes. We may assume that the cottager class was more strongly represented among the unidentified worker emigrants than were the farmers. A cohort analysis made by Brynjulf Gjerdåker indicates that the sons of freehold farmers were the largest group of men that emigrated from Ullensaker. ${ }^{6}$

Of 51 identified craftsman emigrants in the years 1867-84 about one-third originated from the farmer class. These were predominantly younger sons of farmers. Cottagers' sons were surprisingly few among the emigrating craftsmen, but this may be ascribed to the fact that their identification by means of the census material is more difficult.

What was the structure of the farmer emigration? Obviously, the majority within this group were younger sons and daughters of farmers, who had no chance of taking over the paternal property and faced a rather unpromising future by staying at home. An investigation into the economic situation of 25 freehold farmers who emigrated during 1867-75 showed that these were generally the 
owners of small farms. Burdened by debts contracted in connection with property transactions between 1856 and 1865, many of them found themselves in serious difficulties in the crisis of the 1860's.

A similar study of the economic conditions of 15 cottager emigrants during 1867-75 showed that these persons were in an even less favourable situation than the farmer emigrants.

We may ask what became of the farms and the crofts left by the emigrants. About one-third of these places were taken over by other people and, in addition, vacated farms were added to adjoining farms. 10 croft holdings were vacant in Ullensaker in 1875.

When trying to classify the Torslev emigrants according to occupations, we meet with the same difficulties as in the Norwegian material. Emigrants are incompletely registered in the emigration protocols, and it is nearly impossible to identify all emigrants by using the censuses and supplementary sources. Of 192 adult emigrants in the 1870-99 period only 5.2\% belonged to the category "independent within agriculture" (farm owners, tenants etc.), while this group made up $33 \%$ of the total population of Torslev in the same period. On the other hand, agricultural workers, other workers, and servants (both males and females) were strongly over-represented by $86 \%$ of the emigrants - and $51.1 \%$ of the total population.

A closer study of a very limited number of emigrants (48) indicates that emigration intensity among farmer children was about the same as among the sons and daughters of cottagers. But this is a shaky conclusion. We have reason to suppose that the children of cottagers were "hidden" to a greater extent among the workers and servants who emigrated, than was the case of the corresponding farmer group.

In a sample of 80 persons from the Torslev migrants to towns, about $80 \%$ came from the servant/worker class.

As for the Vopnafjordur migrants and emigrants, no classification according to occupational/social status has been made.

The main results of the Nordic micro-studies regarding the structure of the migrant masses may be summarized in the following manner:

On the whole, women were more mobile than men, because they moved more often within their home districts and over shorter distances than the men (Toholampi, Alfta). Women were also generally in the majority among out-migrants to towns (Torslev), although we may find exceptions to this pattern (Ullensaker-born 
in Christiania, 1865). Male migrants tended to be more strongly represented in long-distance migration, and especially in emigration. (Toholampi, Ullensaker, Torslev). The male dominance was most prevalent in the Finnish case, followed by the emigrants from the Danish and the Norwegian districts. Among the emigrants from Vopnafjördur there was, however, a slight majority of women.

The various migration streams were sharply selective concerning the age of the migrants. We find almost invariably that the age group 15-30 years is by far the most apt to move. The 15-29 yearolds were the largest age group in the out-migrations of Toholampi during the 1880 's, and especially the emigration was strongly concentrated; $63 \%$ of the emigrants being 15-29 years old. Total age specific migration intensity was highest in the age group 20-24 years. This was valid for all out-migration and most marked in emigration from the district. But in the migration within the commune boundaries, the 15-19 year-olds had the highest migration frequency relative to their strength in the total population.

The highest mobility of the Alfta migrants and emigrants was registered in the age bracket 25-29 years in the 1870's and among those aged 20-24 in the 1880's. Thus there was a clear tendency for the migrants to become younger within the period investigated.

Among the Ullensaker emigrants during the 1867-99 period, $48.8 \%$ were between 15 and 29 years old. This was a considerably smaller proportion than among the Toholampi emigrants. We should add that this age distribution was above all characteristic of the first emigration wave in 1868-72, which was marked by strong family emigration and a high proportion of children. Later on the exodus to America became an emigration of young persons, and particularly of young men (about 70\% were aged 15-29 in 1892-93 and $66.4 \%$ were males).

Emigrants from Torslev had 60.4\% in the age group 15-29 years. Among the town migrants and the Skxve migrants there were relatively more persons $30-49$ years old. The average emigrant family had more children than the average town migrant family.

It is a salient feature that the emigrants coming from Vopnafjördur had the most balanced age distribution, with the greatest proportion of children (37\%) and people over 30 years old $(32 \%)$. In this district the internal in- and out-migration had a larger proportion of youths 16-30 years old and a smaller number of children.

Family emigration was most prevalent in the Icelandic area 
(about $70 \%$ ) and in the emigration from Ullensaker around 1870. Family representation was least pronounced in the Toholampi emigration, but the families made up $50-60 \%$ of the other outmigrations from the commune in the 1880's.

Unmarried persons moved more often than the married ones. The proportion of married persons among the emigrants from Toholampi was markedly higher $(41.1 \%)$ than among the other migrants from the district $(25-26 \%)$. This does not correspond very well with the low proportion of children among the emigrants. A plausible interpretation is that above all young couples with few children emigrated. A special study of the young emigrating couples from Ullensaker points in the same direction.

When we come to the occupational/social distribution of the individuals in the migrational movements, it is very difficult to compare the results in detail. However, it seems beyond doubt that the poorer and the propertyless segment of the agrarian population was over-represented in the migration streams. Agricultural workers and servant people, younger sons and daughters of farmers and crofters, and to some extent handicraftsmen constituted the great bulk of the migrants. The farmer class seems to be most strongly represented in the Toholampi emigration (52\%). But here the sons and daughters are included, and it is highly probable that these were in the majority in this group. The somewhat diffuse group of servant people and labourers made up 60-80\% of the emigration from Ullensaker and Torslev. In Alfta it was especially the farm hands and servant maids (drangar,pigor) who had a strong migration frequency, and the adult children of farmers and crofters.

The possession of landed property very effectively reduced the inclination to migrate. The same may be said of high age and, to some extent, of marriage. Moreover there were, of course, both economic and psychological barriers to overcome for the prospective migrants. Many potential emigrants did not surmount these obstacles.

\section{Some Special Problems}

Prepaid Tickets

How many of the emigrants had their travelling expenses financed by prepaid tickets? This question has only been taken up in the Ullensaker study. Altogether there were 679 persons, i.e. $40.3 \%$ of 
the emigrants, who received a prepaid ticket during the period 1867-99. In the period 1876-84 the percentage was 50.2. In the final phases of the great emigration waves there were generally more people whose transport was financed in this way; for example, $67.5 \%$ (188 persons) of the emigrants from Ullensaker in 1882-86. Half the number of the families who left during the period 1867-75 travelled on prepaid tickets. As to be expected, the prepaid system was Iess common among the farmers than among the other emigrant groups. On the other hand, it seems to have been very important for the young female emigrants and for the "scattered" emigration of sisters and brothers. In 12 cases during 1869-74 public relief allowances were granted to emigrants from Ullensaker.

\section{Destination in North-America}

This aspect of emigration is only treated in the Finnish microstudy, based on an examination of the Gothenburg passenger lists. About $80 \%$ of the Toholampi emigrants were traced in these lists. Massachussetts, and especially Fitchburg, was the most important destination. It became a kind of tradition for the Toholampi emigrants to go to the Eastern parts of the United States. In the MidWestern area the principal destinations were Hancock and Maquette in Michigan, Minneapolis and Brainerd in Minnesota and Rockford in Illinois. As we have seen, there were relatively few women among the Finnish emigrants: from Toholampi only 31.4\% in the 1878-90 period. However, of those who went to Massachussets $37.8 \%$ were women. The average proportion of women in the entire Finnish emigration from 1878 to 1890 was much smaller, $24.4 \%$. The same is true of the Toholampi emigrants whose destination was in the Mid-West. It was easier for women to find suitable work in the Eastern states. The Toholampi emigrants continued to a great extent to go to Massachussetts also after 1890, and the proportion of women in 1905 was still above the country average (38.5:31.1\%).

\section{The selection of migrants according to reading proficiency}

Kjell Soderberg has presented a special study entitled Reading marks and selective migration in the parish of Alfta 1846-50, 1866-90, where he states that all migration is more or less selective, i.e. it does not reflect the composition of the average population. This has been clearly illustrated in the preceding pages. In doing so, we have exclusively analysed various quantitative aspects of migration/ 
emigration such as sex and age distribution, marital status etc. The Swedish catechetical examination lists also enable us to analyse a qualitative aspect of migration selectivity, namely the reading proficiency of migrants (according to the pastor's notations) compared with that of the stationary population.

This study contains several interesting points. Thus it appeared that the proportion of those with high reading marks was greater among women than men, and greater among unmarried than married persons. This refers to the total population of Alfta. There was a clear correlation between good reading marks and social/ occupational status. However, it was the lower social strata of this parish that had the greatest progress in reading ability in the period up to 1890 . There was also a very positive correlation between the percentage of high reading marks and the degree of communion attendance.

As for the migrants, they generally had a higher proportion of good reading marks than the stationary population (kvarboende). Exception must be made for the emigrants of 1881-85. In the period 1846-50 the emigrants showed the most positive selection, later on the internal out-migrants were far more positively selected with regard to reading ability.

Soderberg also examined in detail the proportion of high reading marks among stationary people versus emigrants, according to age, sex, civil status, occupation, and religiousness (i.e. the number of times a person had attended communion). He gives a more detailed account of his findings in another article in this publication.

A similar study has been made of Koinge parish in Halland, Sweden, by Sune Akerman and others. They found that the distribution of reading marks among migrants graphically described a u-formed curve: both the highest and the lowest marks were overrepresented compared to the total population of the district.'

In concluding this report I would like to emphasize that the local studies made within the framework of the Nordic Emigration project have produced several interesting results and posed questions that may be conducive to further research. They have also thrown into clear relief the difficulties involved in comparative research. This is fully reflected in the preceding survey. Careful planning, firm direction and similarity of method and source material are preconditions of success in this field. 


\section{NOTES}

1 The present article is almost exclusively based on the following studies: Reino Kero, Population movements in Toholampi during the years 1870-1889. Turku 1976; Elisabeth Koren, Utvandringenfra Ullensaker 1867-99. Oslo 1976; Júníus Kristinsson, Emigration from Vopnafjördur 1873-93. Reykjavik 1973; Kjell Soderberg, Alfta socken 1871-1890. Presentation av undersökningsområdet samt av befolkningsrörlighetens bakgrundsvariabler med hjälp av bl. a. AID-analys. Umeå 1974, and Alfta sockens befolkningsrorlighet 1846-50, 1866-90. Presentation av en mikroundersokning samt exempel på några preliminära resultat. Umeå 1976; Arne Vangdrup, Aspekter af Torslev sogns demografiske og migratoriske forhold ca. 1870-1901. Copenhagen 1976.

2 Sivert Langholm, "Short-distance migration, circles and flows: movements to and from Ullensaker according to the population lists of 1865." Scandinavian Economic History Review, vol. 1, 1975, pp. 36-72.

3 Helgi Skúli Kjartansson, Two reports on Icelandic emigration entitled The Background and Statistics. Reykjavik 1975.

4 Andres A. Svalestuen, Tinns emigrasjonshistorie 1837-1907. Oslo 1972, p. 180.

5 Arnfinn Engen, Oppbrot og omlegging. Utvandring og akonomisk utvikling $i$ Dovre på 1800-talet. Oslo 1973, pp. 81-86.

6 Brynjulf Gjerdåker, Geografisk og sosial mobilitet i Ullensaker på 1800-talet. Oslo 1974, p. 80.

7 Sune Åkerman, Per Gunnar Cassel and Egil Johansson, Befolkningsrörlighetens bakgrundsvariabler. Ett försök med AID-analys. Uppsala 1971, p. 44. 